\title{
China-Europe Forest Bioeconomy: Assessment and Outlook
}

Maarit Kallio, Xiaoqian Chen, Ragnar Jonsson, Janni Kunttu, Yijing Zhang, Anne Toppinen, Jianping Zhang, Jiancheng Chen, Nike Krajnc, Ben Cashore, Bo Yu, Chen Yong and Davide Pettenella 


\section{Authors}

Maarit Kallio, Norwegian University of Life Sciences, Norway

Xiaoqian Chen, European Forest Institute

Ragnar Jonsson, European Commission, Joint Research Centre

Janni Kunttu, European Forest Institute

Yijing Zhang, South China Agricultural University, China

Anne Toppinen, University of Helsinki, Finland

Jianping Zhang, Institute for International Economic Research of National Development and Reform

Committee, China

Jiancheng Chen, Beijing Forestry University, China

Nike Krajnc, Slovenian Forestry Institute, Slovenia

Ben Cashore, Singapore National University, Singapore

Bo Yu, Institute of Microbiology, Chinese Academy of Sciences, China

Chen Yong, Chinese Academy of Forestry, Institute of Information and Policy, China

Davide Pettenella, University of Padova, Italy

\section{ACKNOWLEDGEMENTS}

The report benefited from the helpful comments from external reviewers, Elias Hurmekoski from the University of Helsinki and Su Haiying from the Chinese Academy of Forestry. We wish to express our thanks for their insights and comments that helped to improve the report, and acknowledge that they are in no way responsible for any remaining errors.

This work and publication has been financed by EFI's Multi-Donor Trust Fund for policy support, which is supported by the governments of Austria, Czech Republic, Finland, Germany, Ireland, Italy, Lithuania, Norway, Spain and Sweden.

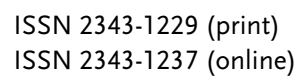

Disclaimer: The views expressed in this publication are those of the authors and do not necessarily represent those of the European Forest Institute, or of the funders.

Recommended citation: Kallio, M., Chen, X., Jonsson, R., Kunttu, J., Zhang, Y., Toppinen, A., Zhang, J., Chen, J., Krajnc, N., Cashore, B., Yu, B., Yong, C., Pettenella, D. 2020. China-Europe Forest Bioeconomy: Assessment and Outlook. From Science to Policy 11. European Forest Institute. https://doi.org/10.36333/fs 11 


\section{Contents}

Executive summary.

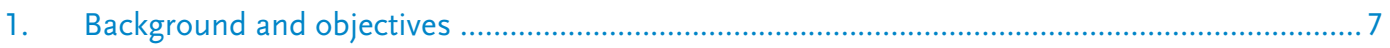

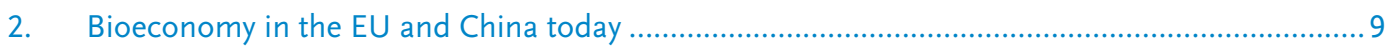

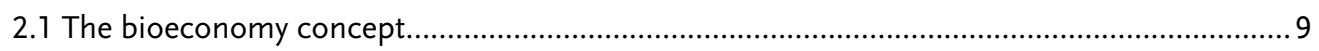

2.2 Key strategic objectives and supporting policies for forest bioeconomy ............................ 11

2.3 The forest-based bioeconomy as part of the economies of China and the EU ................... 14

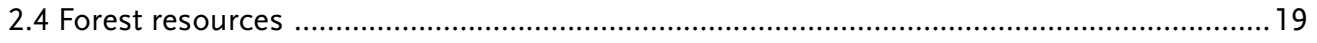

2.5 China-Europe bioeconomy cooperation development .......................................................... 22

3. Climate and sustainability policies related to the bioeconomy ................................................2 24

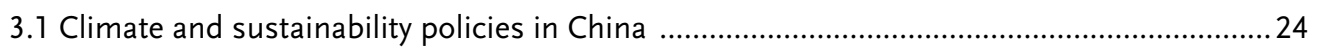

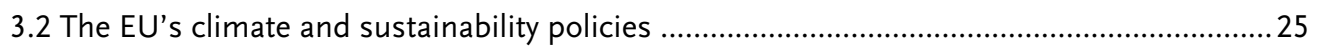

4. Outlook for China-Europe forest bioeconomy development to 2030 ......................................26

4.1 Key factors influencing forest-based bioeconomy development..........................................26

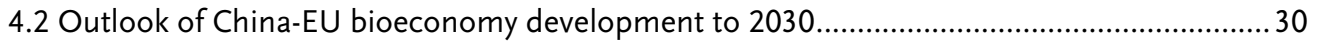

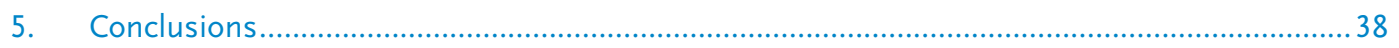

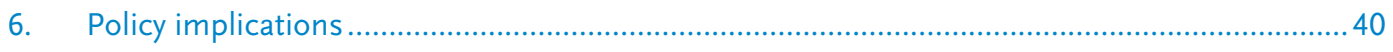

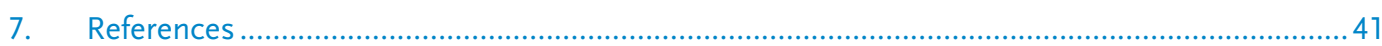


$T^{n}$ he European Union and China are two of the three biggest economies and trading blocs in the world, and their economic and trade relations are increasingly interlinked. China's role as an export destination for forest products made in the EU, as a potential source or destination of capital for developing the forest-based sector, and as Europe's key partner in climate change mitigation has increased in importance, especially in the last decade.

While a sustainable circular bioeconomy has been recognised and discussed in Europe, for example in the European Commission's EU bioeconomy strategy in 2018 , the bioeconomy is still a new concept in China.

China is by far the largest global producer and consumer of concrete, steel, coal, paper and oil-based products such as polyester fibre and plastic. A shift from a fossil fuel-based economy to a greener, more circular and less carbon intensive economy is needed, if China is to succeed in its aim of making its economy climate neutral within the next 40 years (by 2060). Technologies, products and policies are needed to support these objectives in all economic frontiers.

Dialogue and cooperation on green development between the EU and China has deepened under the EU-China Comprehensive Strategic Partnership, which embraced its seventeenth anniversary in 2020. In 2018, China and the European Commission signed a Memorandum of Understanding on Circular Economy Cooperation. Further cooperation within the area of bioeconomy could contribute to China's sustainable development and provide important market opportunities for bioeconomy sectors in the EU in the coming decades.

To evaluate the opportunities, there is a need for an overview of forest bioeconomy development in the two regions, an analysis of the interactive impacts along the supply chain, and foresight on the impacts caused by policy and market changes. This study provides the first systematic assessment of the potential challenges, future possibilities and policy implications for Europe-China forest-based bioeconomy development.

\section{Conclusions}

Developing a sustainable circular forest bioeconomy is in the interests of both the EU and China in order to enhance socioeconomic wellbeing while also safeguarding natural resources. Forest resource scarcity calls for social and technical innovation, leading to more efficient and circular uses of biomass resources. It also creates business opportunities within waste management, recycling, material development, cascading production concept development, and design of biorefineries and industrial ecosystems. In the new evolving urbanised areas in China, waste management and green city thinking will be easier to implement than in already established urban structures. The lessons that will be learned from implementing the EU waste regulation on textiles, paper and wood materials recycling form a promising area of R\&D cooperation between the EU and China.

Policies affecting consumer and industrial behaviour are needed to accelerate bioeconomy development. Recent regulations in China and the EU that aim to reduce the use of plastics in several application areas are one example. China's growing construction market is the largest in the world and the use of green building materials is supported by policies in China. This should also provide market possibilities for EU producers of engineered wood products and softwood sawnwood.

The combination of current scarce domestic wood supply and growing wood and forest product demand in China is likely to increase the interests of Chinese companies in foreign investments in forests and forest-based industrial activities abroad. At the same time, China is investing heavily in its own forest resources, which may shift the focus of Chinese 
investments in the EU to basic resources rather than greenfield industrial capacity with a long lifetime. To be prepared for using its own growing domestic resource, China is likely to be interested in R\&D cooperation with EU partners.

Investments by EU actors in the bioeconomy in China are complicated by restrictive foreign investment policies and entry barriers. If these barriers can be overcome there should be remarkable opportunities - for example, in creating infrastructure and business in recycling and reusing of biomaterials, production of innovative wood-based packaging and packaging materials, and construction of healthy buildings using engineered wood products.

Forest bioeconomy-related innovation, new practices and knowhow require considerable R\&D investment and risk taking. The EU should prioritise this multidisciplinary research, allocating more funding to it and to the pilot applications needed in order to advance them to the commercial stage. The EU risks being left behind, as it is difficult for it to match China's investment in R\&D funding and resources. The EU could also establish platforms for green funding, for example green bonds. China is a forerunner in such funding arrangements, and R\&D collaboration between China and the EU in these areas provides an opportunity for both parties.

Political trust between China and the EU is the key to collaboration and prosperous trade. In recent years, there have been some challenges in this respect. Both regions should make serious efforts to build better trust in the future, as forest bioeconomy cooperation will require policy exchange, joint research activities, knowledge sharing and business dialogue.

\section{Policy implications}

- Wood biomass scarcity calls for an increase in the resource base and, inherent in the concept of bioeconomy, using existing resources more smartly. China and the EU would benefit from cooperation in both areas and could collaborate in:

- Research, monitoring and exchange of knowledge and best practices regarding enhanced joint production of economic, social and environmental ecosystem services from forests.

- Developing, identifying and copying novel or best practices for: collecting and reusing materials; manufacturing products with the same or improved functionality using less resources; increasing product lifetimes; and influencing consumers to adopt more sustainable consumption habits.

- Chinese markets for wood-based packaging, textiles and construction materials provide vast business opportunities. For EU-based industries to benefit from these opportunities, EU policymakers need to provide information, support for R\&D and risk financing, and also ensure a stable policy environment that safeguards the reliable supply of biomass.

- In order to ensure that bioeconomy development is sustainable, its development must be guided in a way that guarantees sustainability (including biodiversity considerations), and the development must be monitored. If necessary, new regulations must be imposed to ensure sustainability.

- To monitor and evaluate forest bioeconomy development, and to assess related market opportunities, harmonised and more reliable statistical data is needed on forests, the forest-based sector and other relevant sectors. Efforts should be made to improve statistical systems.

- To strengthen bioeconomy development, China and the EU need to finally accomplish their bilateral investment agreement (negotiations started in 2013) that ensures equal rights, obligations and access to respective markets for investors from the EU and China. Harmonised standards for Chinese and European 'green' investing would enhance foreign investments and sustainable technology development, especially in China. 


\section{Background and objectives}

The EU and China are two of the three biggest economies and leading traders in the world, and their economic and trade relations are increasingly interlinked. In terms of forest area China (220 million hectares) is bigger than the EU-27 (I80 million hectares), but in terms of the value of the exports of wood and forest industry products, EU ( 88 billion EUR in 20I9) is seven times bigger than China (I2 billion EUR) (FAOSTAT, 2020 ). China's roles as an export destination for forest products made in the EU, a potential source or destination of capital for developing the forest-based sector, and Europe's key partner in climate change mitigation have increased their importance, especially in the last decade.

Climate change, degradation of biodiversity, environmental pollution and the limitations of natural resources call for a revolution in the economic system in order to satisfy the needs of a growing - and increasingly middle class - population in a sustainable manner. Transformation from a fossil fuel dependent economy towards a circular bioeconomy has been considered to bring the world one step closer to more sustainable production and consumption systems. At the same time, innovations, industrial development and structural renewal are needed in all economic sectors. The European Union defines the bioeconomy to include all sectors and systems that rely on sustainable use or reuse of biological resources. The bioeconomy thus comprises all primary production sectors that use and produce biological resources and services (agriculture, forestry, fisheries and aquaculture) and all economic and industrial sectors that process or recycle these resources further to produce food, feed, bio-based products, energy and services. Sustainability and circularity are two important requirements for bioeconomy (European Commission, 2018a). Almost 50 countries have developed a bioeconomy strategy or included bioeconomy in their national development strategy (German Bioeconomy Council, 20I8). In last decade, the global bioeconomy market has grown substantially, and novel products and technologies have been developed.

Forests are the biggestland-based, non-food renewable resource with important potential to contribute

I FAO statistics exclude wooden furniture and some other finished products. to the bioeconomy (Hetemäki et al., 20I7). The EU bioeconomy strategy (European Commission, 20I8a) states that the forestry sector can provide bio-based materials and products for construction, packaging, textiles, furniture and chemical industries to replace less sustainable materials and products, while new business models, enhanced value creation opportunities and wellbeing can also be derived from the forest ecosystem services. The strategy also calls for better understanding of the ecological boundaries for the bioeconomy.

While a sustainable circular economy has been recognised and discussed in Europe as one of the pathways that help to achieve the United Nations sustainable development goals (SDGs) bioeconomy is still a new concept in China. As a country, China is by far the largest producer and consumer of concrete, steel, coal, paper and oil-based products, such as polyester fibre and plastic. A shift from a fossil fuel-based economy to a greener, more circular and less carbon intensive economy is needed in China to support economic reform, meeting the climate change commitments, and implementation of SDGs, on a national level. China has set goals to decrease $\mathrm{CO}_{2}$ emission per unit of GDP and to increase the share of non-fossil energy in its energy consumption. Within the next 40 years, China is aiming to make its economy climate neutral. Technologies, products and supportive policies are needed to support these objectives in all economic frontiers.

Dialogue and cooperation between the EU and China on green development has deepened under the EU-China Comprehensive Strategic Partnership, which embraced its seventeenth anniversary in 2020. Cooperation within the bioeconomy could contribute to China's sustainable development and provide important market opportunities for bioeconomy sectors in the EU in the coming decades. To evaluate the opportunities, an overview of forest bioeconomy development in the two regions, an analysis of the interactive impacts along the supply chain, and foresight on the impacts caused by policy and market changes are needed. Until now, no systematic assessment of the potential challenges, possibilities and policy implications is available on European-China forest-based bioeconomy development. The purpose of this study is to provide such 
an assessment of the current situation and an outlook for the rest of the decade.

The objectives of the study are, first, to:

- Review China-Europe bioeconomy policy development over the past 20 years.

- Track the forest bioeconomy market and trade development in China and Europe over the past 20 years.

- Analyse climate change and sustainable development policies in China and in the EU and their impacts on bioeconomy and trade between the two regions.

- Provide foresight for China-Europe forest bioeconomy trade and market development up to 2030 .

Based on the above review and assessment, the following topics will be analysed further:

- China as an export region for European forest bioeconomy products.

- China as an investment location for European forest bioeconomy companies.

- Chinese companies as investors in forest bioeconomy in Europe.
Although the term 'Europe' is used above and often later on, the study focuses on connections in the bioeconomy area between the $\mathrm{EU}^{2}$ and China. This choice was made because of the heterogeneous nature of bioeconomy developments across the whole of Europe and because of the different policy objectives of the different European regions with China. Also, the data on forest bioeconomy and its development is more systematic and readily available from the EU than some other parts of Europe. Furthermore, due to limited data availability on the many essential social and environmental benefits provided by forests, this report will largely focus on the marketable products and services provided by the forest-based bioeconomy.

2 The abbreviation EU-28 will be used to refer to EU data that includes the United Kingdom, while EU-27 excludes the United Kingdom. When the text reads "EU" without further specification, the above division is not very relevant, though it can be interpreted as referring to the EU-27. 


\section{Bioeconomy in the EU and China today}

\subsection{The bioeconomy concept}

Following the definitions by Palahí et al. (2020) and Hetemäki et al. (20I7), circular bioeconomy includes and is achieved through the provision of ecosystem services and the sustainable management of biological resources (plants, animals, organic waste) and its circular transformation in food, feed, energy and biomaterials within the ecological ecosystem boundaries (Fig. I). Circularity not only encompasses the idea of cascading production but also of producing goods and services with minimal input and minimal system waste.

Forest-based bioeconomy includes all economic activities relating to forests and forest ecosystem services. Environmental and social sustainability are important aspects of forest bioeconomy: the part of bioeconomy that uses wood as raw material must be in balance with the other social and ecological functions of forests. The future evolution of the

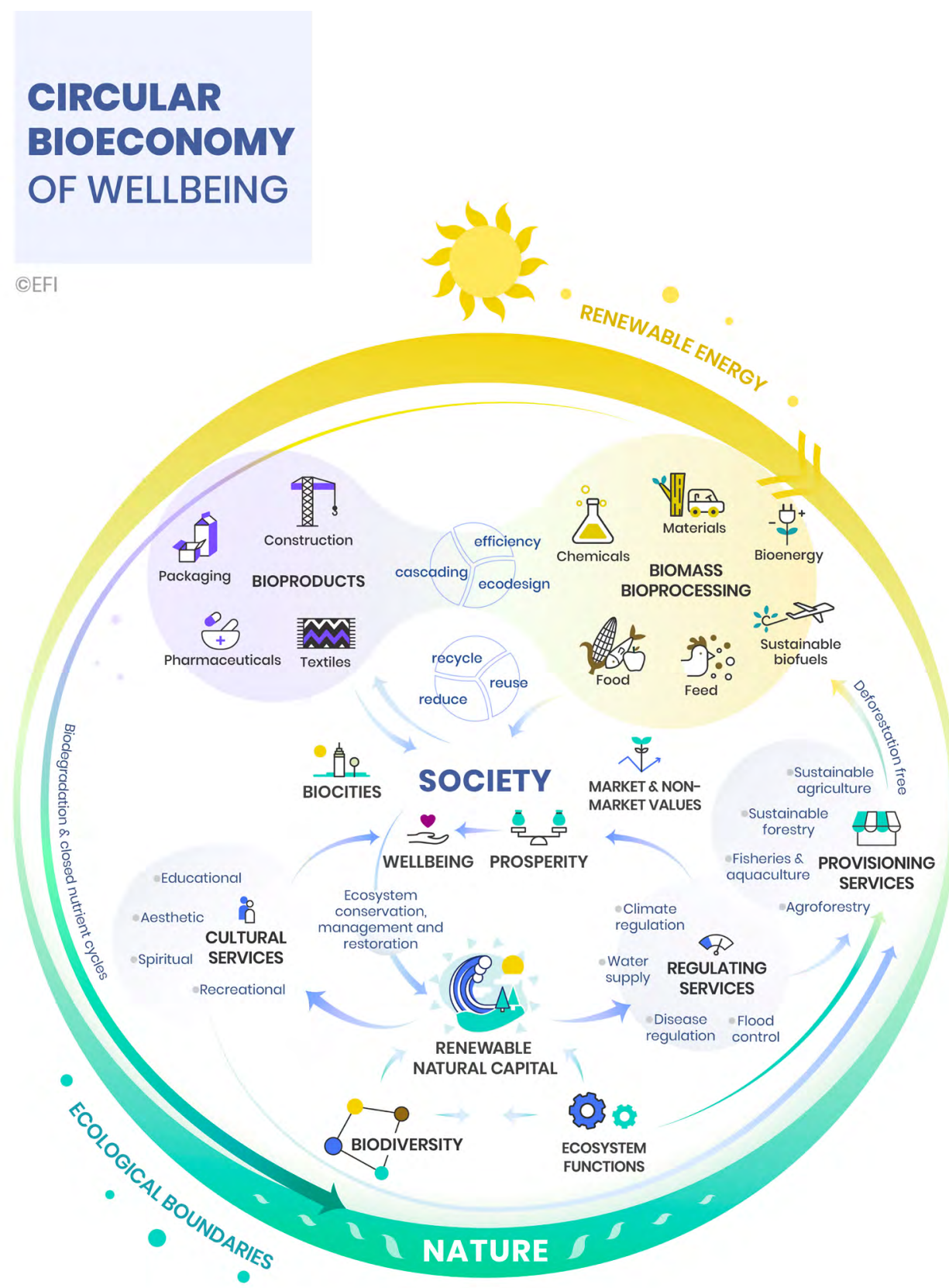

Figure 1. Illustration of circular bioeconomy flows. Source: Palahí et al. (2020). 
forest bioeconomy needs to involve an inclusive network of multiple sectors and actors including civil society (eg consumers, forest owners), the private sector (including industries), as well as academia and policymakers.

Bugge et al. (2016) suggest that the bioeconomy concept could be approached from three visions: I) a bio-technology led vision that emphasises the importance of R\&D in bio-technology and its commercialisation; 2) a bio-resource led vision that sets focus on processing and upgrading biological raw materials and on the new supply and value chains; and 3) a bio-ecology vision, which emphasises the role of sustainability.

The European bioeconomy concept focused initially on traditional bio-based materials and energy without specific emphasis on material circularity. The European Union Action Plan for Circular Economy (European Commission, 2015) called for resource efficiency by keeping the value of materials, products and resources in the technological 'closed loop' system as long as possible. The EU Bioeconomy Strategy (European Commission, 20I2, 20I8a) connects the renewal of bio-based manufacturing sectors to meeting the global sustainability challenges and includes features of all three bioeconomy visions above.
In China, bioeconomy discussion is coupled with finding a better balance between economic development and environmental protection. The aim of shifting from a fossil fuel-based economy to a more environmentally sustainable economy has been included into the Chinese national strategy since 2007. Green economy, circular economy, low carbon economy and bioeconomy have all been discussed as possible pathways for balancing economic development, environmental protection and social wellbeing. Yet, these concepts have had different focuses (Fig. 2). Forest bioeconomy is still quite a new and evolving concept in China. Thus, it is not very visible in national or sectoral policies and strategies, or in research. It often refers to economic activities based on renewable biological resources and includes bioproducts and materials production, processing and consumption to achieve green growth and sustainable development (Deng, 20I8). Furthermore, the bioeconomy concept relates strongly to the biotechnology industry in China. In 2007, China's Ministry of Science and Technology issued strategies to speed up the development of the biotechnology industry. The industry was included in the industrial development priorities in the twelfth (2OII-2OI5) and thirteenth (2016-2020) National Five Year Plans (FYPs). The

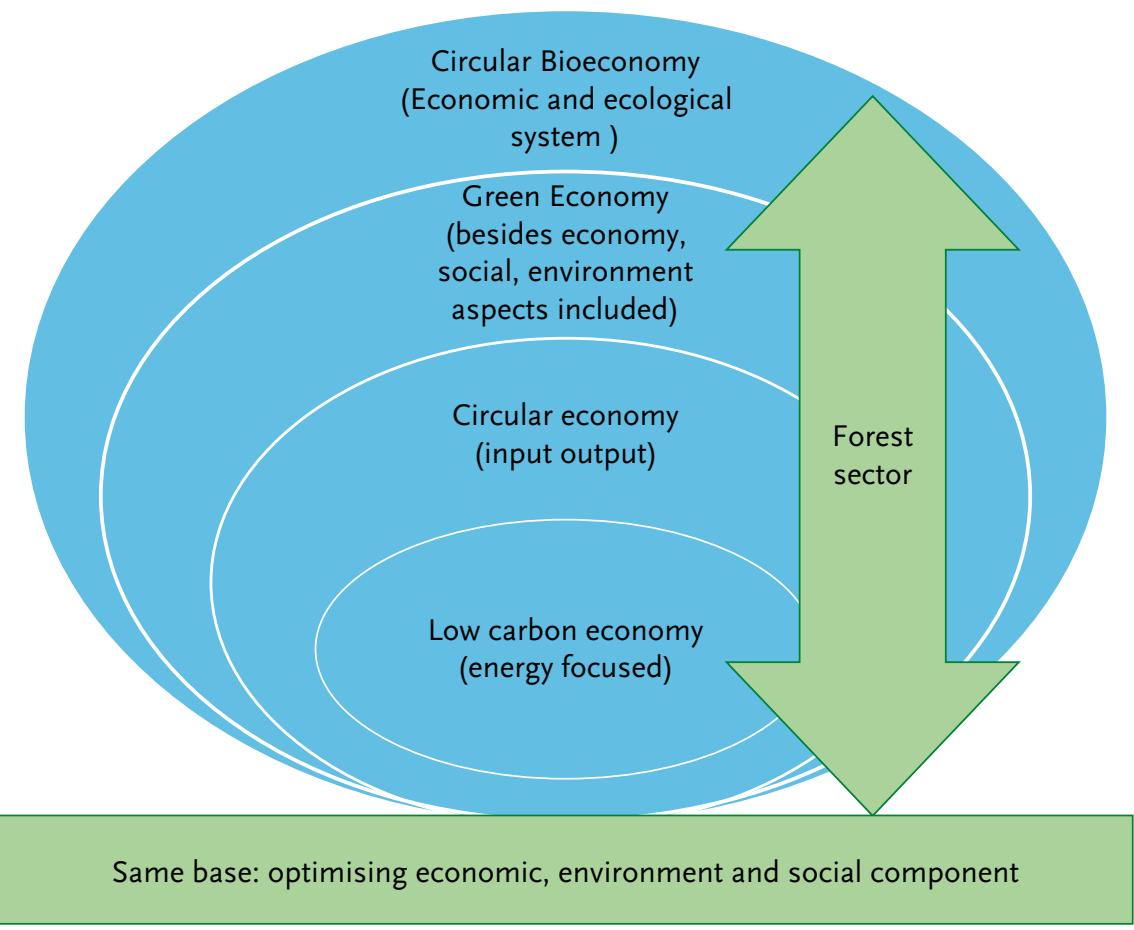

Figure 2. Bioeconomy related concepts in China. Source: edited by the authors. 
biotechnology innovation plan in the thirteenth FYP defines biomedicine, biochemicals, bioresources, bioenergy, agriculture, environmental protection and biosecurity among the biotechnology development priorities up to 2020 (Ministry of Science and Technology, 20I7). Bioeconomy was considered for the first time as a new economic model in a Central Economic Work Conference document in 2017 (Deng et al., 2020). That signalled political commitment to supporting bioeconomy development.

While this report is solely focusing on forest bioeconomy in the EU and China and its development in a relative short time period, up to 2030 , the following notions are important to keep in mind. Bioeconomy is not a goal itself, but one of the necessary means for the creation of wellbeing in a more environmentally and socially sustainable manner than that achieved by 'business as usual' economic development. Bioeconomy is not expected to solve big global challenges such as resource overconsumption, pollution and environmental degradation alone. Parallel and substantial advances are equally needed across all other social and technological frontiers. Innovations in the latter may well play a decisive role in the longer run and change the world we live in completely. Meanwhile, enhancing the renewable natural resource base and using both renewable and non-renewable natural resources smartly should be beneficial for the human wellbeing in any possible unforeseeable future. Finally, bioeconomy is not assumed to be economically, environmentally or socially sustainable by default, but its sustainability should be monitored and studied like that of any sector outside of bioeconomy.

\subsection{Key strategic objectives and supporting policies for forest bioeconomy}

\subsubsection{Key objectives and policies in the EU}

The EU's bioeconomy strategy (European Commission 2012, 2018a) is driven by the need to change patterns of production, consumption, processing, storage, recycling and disposal of resources in order to cope with increasing global population, depletion of resources, increasing environmental pressures and climate change.

In its first stage (European Commission, 20I2), the strategy recognised bioeconomy as a key element for the sustainable, smart and green economic growth in Europe. The main objectives were to help tackle the societal challenges of:

(i) Ensuring food and nutrition security.

(ii) Managing natural resources sustainably.

(iii) Reducing dependence on non-renewable, unsustainable resources whether sourced domestically or from abroad.

(iv) Mitigating and adapting to climate change.

(v) Strengthening European competitiveness and creating jobs.

The updated strategy (European Commission, 20I8a) further emphasises the circularity aspect of the bioeconomy and, within ecological boundaries, the need to accelerate bioeconomy deployment in order to contribute to the Paris Agreement and to the UN's 2030 Agenda for Sustainable Development and its Sustainable Development Goals. Services related to the bioeconomy are also highlighted, along with the goal of plastic-free seas and oceans.

Among the challenges listed in the initial bioeconomy strategy of 20I2, those listed under (ii-v) are most directly tied to the forest-based bioeconomy. Managing natural resources sustainably (ii) involves eg smart, sustainable production of forest biomass, reduction of degradation of forest environment and biodiversity, ecosystem-based forest management, and sustainable and efficient use of forest resources. Reducing dependence of non-renewable resources (iii) involves resource efficient industries, bio-based products and bioenergy in their diverse forms (eg bioplastics and textiles), new industries, processes and value chains. These businesses also contribute to the core policy objective (v) of green growth and competitiveness. Mitigating and adapting to climate change (iv) mean a decrease of greenhouse gas emissions by substituting more carbon intensive products for products based on sustainable forest biomass, increasing carbon storage in the harvested wood products, and enhancement of forest resources and, thereby, carbon sinks.

The EU has no common forest policy ("competence in forest policy" in the EU jargon) or policies particularly aimed at promoting the forest bioeconomy. There are, nevertheless, various, sometimes conflicting, policies supporting the key objectives of the bioeconomy strategy.

For example, the EU's legislative framework on waste (European Commission, 20I8b) enforces targets such as recycling $65 \%$ of municipal waste 
including paper, textiles and wood materials by 2035 , and $70 \%$ of packaging waste by 2030 . Specific recycling targets are set for paper and paperboard $(85 \%)$ and wood (30\%).

The land use, land use change and forestry (LULUCF) regulation for 202I-2030 (European Parliament and the Council, 2018a) defines new rules for carbon accounting in forests and other land and provides new guidelines for updating the reference levels of forest carbon sinks for accounting purposes.

The updated renewable energy directive (European Parliament and the Council, 20I8b) requires $14 \%$ of the final energy used in road and rail to be renewable by 2030 . The minimum share of so-called advanced biofuels is set at $3.5 \%$ by 2030 . These fuels can be made for instance from several alternative lignocellulosic feedstocks, ie wood.

The directive on reducing the environmental impacts of plastic products (European Parliament and the Council, 20rga) will ban the use of various single-use disposable plastic products by 202I, eg cutlery, plates and straws, and cups or meal containers made of expanded polystyrene. These products can be relatively easily replaced by, for example, products made of paperboard.

Other policies supporting forest bioeconomy are Natura 2000, EU Forest Strategy (European Commission, 20I3) 3 , and the Bioeconomy Observatory.

In addition to binding regulations, the EU's innovative industrial initiatives (eg European Parliament and the Council, 2013) and Horizon 2020 programme include promoting the production and distribution of energy derived from renewable sources, protecting and restoring biodiversity and soil, promoting ecosystem services, promoting climate change adaptation, and risk prevention and management through, for instance, ecosystem-based approaches.

In December 2019, the European Commission presented the European Green Deal (EGD), an ambitious package with the overarching aim of making Europe climate neutral by 2050 (European Commission, 2019a-c). EGD would imply tightening the greenhouse gas reduction goal for 2030 to at least $50 \%$ instead of the current $40 \%$. It also entails a review of EU laws and regulations to align them

3 The new EU Forest Strategy is under process and is expected to be launched in 202I. with the new climate goals (European Commission, 2orga).

\subsubsection{Key objectives and policies in China}

There are no policies or strategies set for circular bioeconomy in its full width (Fig. 2) in China. However, since 2010, along with China adopting the sustainable and green development model, several policies have been issued or revised to support economic concepts within the bioeconomy: circular economy, green economy and low carbon economy. These policies can be categorised according to their legal validity and coverage as follows (see Fig. 3).

- National legislation: national coverage, legally binding requirement with clear punishment measures, and normally followed by implementation regulations.

- National strategies: of a voluntary nature, providing a roadmap, outline or guide for certain area development in a certain time frame on a national level.

- Sectoral and local policies: of a voluntary nature, targeting a certain sector or geographical area, such as a province or city, and usually developed according the related national strategy or plan.

- The documents of Tong Zhi, Yi Jian and Fang An: micro-level operational guidelines of a voluntary nature with certain targets.

The policies in Figure 3 and several others support forest-based bioeconomy development in China. It is not possible to review them all here, but below we give some examples.

The Green Building Action Plan (2013) aims to reduce greenhouse gas emissions from the building sector. It promotes the use of materials considered to be green, especially in terms of energy-efficiency but also in terms of other environmental aspects. Use of wooden materials is encouraged by Promoting Green Construction Materials Production and Utilization (20I5) and the more recent Green Building Creation Plan (2020), which issues specific targets for green building development. Since 2014, the Chinese government has promoted modern wood-structure buildings with a series of policies. In 2015, the Ministry of Industry and Information Technology proposed a notice to develop differentiated wood-structure buildings in different areas. In rural tourist resorts and rural areas, wood-structure buildings are highly promoted. In economically developed 


\section{National legislation}

National strategy policy
- 1989, 2014r Environment Protection Law

- 2006, 2009r, Renewable Energy Law of the People's Republic of China

- 2002, 2016r, 2018r, Clean Production Promotion Law (amended in 2012).

- 2008, 2018r, Circular Economy Promotion Law.

- 1985, 2019r Forest Law

- National Climate Change Plan (2014-2020) low carbon industry

- National new urbanisation outline (2014-2020) set green building development goal, to 2020 , green building account for $50 \%$.

- Green Industry Development Plan (2016-2020)

- Thirteenth Five Year Plan (2016-2020) highlighting the green development

- National Forest Management Outline (2016-2050).

- Green Public procurement advice list

\section{Sector and provincial} level policy
- 2013 Green Building Action Plan.

- 2014 Energy Development Action Plan 2014-2020

- 2015 Manufacture 2025 (2015-2025)

- Fu Jiang Province Energy development outline (2016-2020)

- 2016 Forestry sector's action plan to adopt the climate change (2016-2020)

- 2017 Forestry sector's action plan to support China's National Plan on Implementation of the 2030 Agenda for Sustainable Development.

- 2015 Guidelines for Establishing the Green Financial System

- 2015 Green construction production and use outline, promote using wood building was highlighted.

- 2016 State Council: Yijian to promote new urbanisation and support wood building.

- 2016 NDRC: Improving city's climate adaptation ability, promoting wood building is part of it.

- 2016 The Ministry of construction: Yijian to promote green building materials produce and using, wood construction is part of it

- 2016 State Council: Yijian to promote prefabricated concrete structure in building and support wood building

- 2020 Green Building Creation Plan with specific targets for green building development.

Figure 3. China's bioeconomy related polices and strategies and the year of promulgation or revision (Revision year is marked by "r", eg 2018r). Source: edited by the authors.

rural areas, the construction of wood-structure selfbuilt houses and new-build settlements are recommended. In urban areas, wood structures in public schools, kindergartens, nursing homes, gardens, and other low-rise public buildings are encouraged. In 2016 , the State Council further called for a speeding up of the industrialisation process of prefabricated buildings, especially in major urban agglomerations such as Beijing-Tianjin-Hebei, Yangtze River Delta, and Pearl River Delta. The aim is that prefabricated buildings account for about $30 \%$ of new-build building areas in 2026 .
The Clean Production Promotion Law promotes the use of resource-efficient low waste and low pollution technologies, recycling and reusing wastes when that is economically and technically feasible, and prioritising environmentally friendly, recyclable products. The Circular Economy Promotion Law shares the same reduce, reuse and recycle principles, requiring efficient and circular use of resources, including waste, energy, land and water. One of its articles encourages industrial parks to organise the firms belonging to them to follow the principles of the circular economy. 
The recent roadmap against plastic pollution aims to limit plastic product usage by 2025 , and totally ban some of it (NDRC, 2020). The measures taken in the whole country, or in certain regions, include banning over the coming years, for instance, sales or use of thin plastic bags, use of non-degradable plastic bags in retail sales, use of non-degradable disposable cutlery and plastic straws in restaurants and takeaways, and use of disposable plastic products in hotels. The policy also recommends using paper and other environmentally friendly products to replace the non-degradable plastic products.

The newly revised Forest Law continues to embody the principle that ecology comes first in forest development in China and emphasises forest protection. It also clarifies forest ownership and strengthens property rights (Ministry of Natural Resources, 20I9). Forest management units are assigned more rights on deciding eg on harvest volumes in commercial forests. The reform may lead to more efficient implementation of the National Reserve Forest Programme (NFGA 20I9a, see chapter 2.4.2) which aims to increase China's domestic wood supply by 2035 and reduce China's high dependence on log importation. The previous programmes have had slim results and led to forest areas with low stocking and weak productivity. The lack of economic incentives, in the form of expectations of future timber sales income, and top-down command by the state and other authorities, have been important reasons for that (Hou et al., 2019). An important amendment in the forest law is that it includes the ban on (knowingly) buying, transporting and processing illegally sourced timber, and that it requires companies to keep accounts of their raw materials and products. The law as it is written may leave open the possibility that operators could claim to be unaware of the true origins of the roundwood they use. Nevertheless, it gives a signal to the operators and is a positive step forward. If enforced strongly, the law may help curb the use of roundwood from illegal origins.

Guidelines for Establishing the Green Financial System (2015) kicked off the work on green financing for supporting green development, with 35 concrete implementation actions. The green financing launched in China is divided into green credits, green industries and green bonds (Ma et al., 2020). The Chinese green bond market is currently the world largest, despite the fact that roughly one quarter of the bonds considered green in China may not be regarded as green by international investors (Meng and Filkova, 20I9).

The Made in China 2025 initiative, launched in 20I5, aims to modernise China's industrial capability to produce high-tech goods and advanced manufacturing (see eg ISDP, 20I8). If successful, China would move up the value-added chain from a low-cost manufacturer to a more competitive player globally and finish its transition into a developed economy. Among the Io prioritised industries, "new materials" seems the most relevant for the bioeconomy.

\subsection{The forest-based bioeconomy as part of the economies of China and the EU}

\subsubsection{Size of the bioeconomy and related markets}

Forest-based bioeconomy and related markets in the EU The added economic value and contribution to employment of the bioeconomy are difficult to estimate, because the bio- and non-bio industries are largely mixed. The European Commission Joint Research Centre recently introduced an improved classification method which accounts for the bioeconomy contribution of the industries based on their biobased shares of the inputs and outputs (Kuosmanen et al., 2020). The new method also includes the service sector in the calculation ${ }^{4}$. Using the method, the value added of the total bioeconomy in the EU28 in 2015 was estimated at I. 46 trillion EUR, having II\% share of the GDP (Kuosmanen et al., 2020). Further, it was estimated that almost 34 million people worked within the bioeconomy in 2015, making up $15.4 \%$ of all employment. The report does not provide separate figures for the forest-based bioeconomy. Using an earlier methodology that gives a smaller overall size of the bioeconomy, Piotrowski et al. (2019) estimated that forestry and the forest-based industries accounted for $18 \%$ of the turnover and $15 \%$ of the employment in the EU-28 bioeconomy in 2016.

The forest-based sector has a crucial role as a provider of renewable substitutes for non-renewable materials, products and energy in the EU. In 20I8, the $\mathrm{EU}$ was the largest producer and consumer

4 Yet, like any method, it does not consider the value of the ecosystem services, for which systematic data is lacking. 
of roundwood and the largest producer and second-largest consumer of sawnwood in the world. Further, it was the second largest producer and consumer of pulp for paper, wood-based panels, and paper and paperboard (FAOSTAT, 2020).

As the growth in consumption of traditional wood-based products is increasingly shifting to the rapidly growing large economies of China, Brazil and India, the growth of these industries in the EU depends on successfully increasing business in export markets. In more mature markets such those of the EU, the market opportunities are increasingly related to winning the markets from other materials, for instance by replacing other textile materials with wood-based ones or replacing concrete and steel by their wooden alternatives in the construction sector. These substitution-based market opportunities also exist, of course, in the export regions. Furthermore, biochemicals, biofuels, packaging and bioplastics provide promising emerging markets for wood-based products (Hurmekoski et al., 20I8). When it comes to advanced biofuels produced from residues and wastes from forest-based industries, demand for them is chiefly driven by policy.

Forest-based bioeconomy and related markets in China There is no direct statistical data available on the size of the Chinese bioeconomy. The production value of the green low carbon industry (including industries that are energy saving and environmentally friendly, ecological industry, and new energy industry) is expected to reach I.25 trillion EUR by 2020
(State Council of China, 2or6). As for the forest sector, the forest industry production value was 929 billion EUR in 2018 (NFGA, 20Igb).

The consumption of timber products in China increased by $60 \%$ from 2007 to 2017 and reached 568.5 million $\mathrm{m}^{3}$ in $20 \mathrm{I7}$, measured in terms of $\mathrm{log}$ consumption. The construction sector and pulp and paper industries are the two largest users of wood, accounting for roughly $60 \%$ of wood consumption in China (Fig. 4). The Chinese wood furniture industry is the largest in the world. In 20I7, it had an almost $12 \%$ share of wood consumption in China (NFGA, 20I9b). In recent years, China has faced challenges in further enhancing its share of the global forest industry value chain due to rising labour costs and strengthened international awareness of the sustainability of the wood material used (Hou et al., 2016; Su et al., 2020).

China has a long history of constructing traditional wood buildings with a mortise and tenon joint structure, called 'Sunmao'. However, the forest logging bans China implemented to protect the natural forests have reduced the log harvest since I998 and marginalised the use of wood as a construction material. The highest growth in building construction is in the rapidly growing urban areas. Urbanisation and economic development have made China the biggest construction market in the world, but steel, concrete, bricks and glass dominate as construction materials. The modern wood-structure buildings only account for some $0.35 \%$ of the building stock in China (He et al., 20I9). However, this

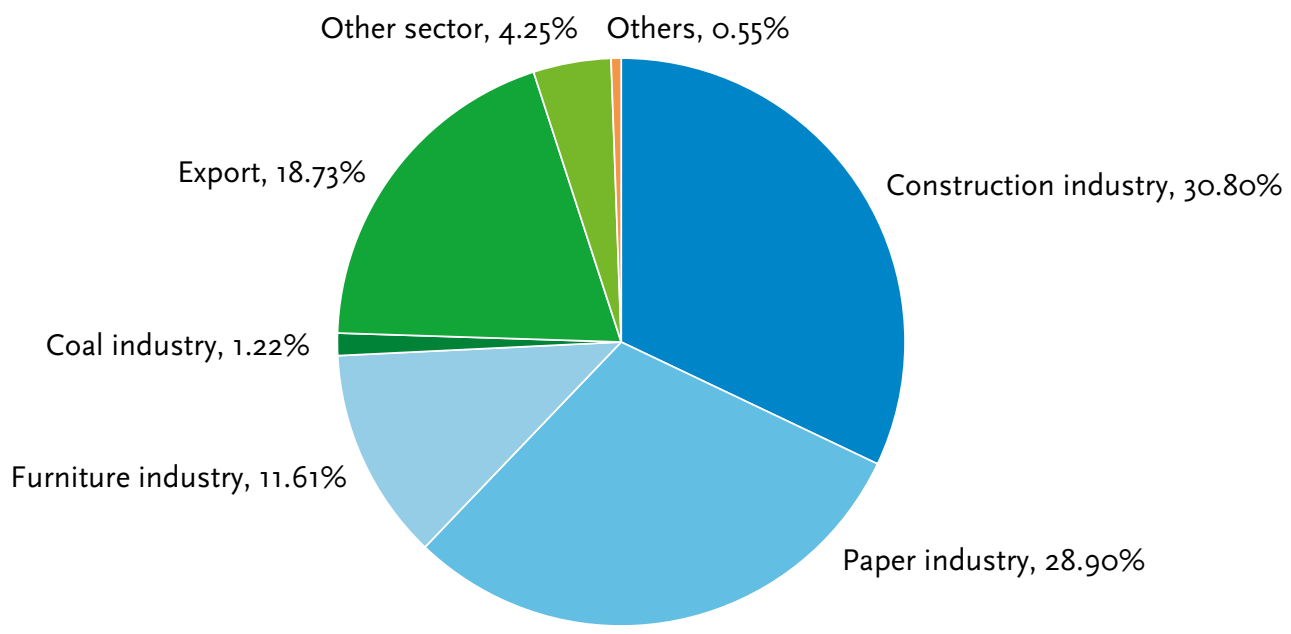

Figure 4. Structure of wood consumption in 2017. Source: NFGA. 
market is experiencing a rapid growth. The aggregated wood construction building area was estimated to be in the range of ${ }^{2} 2-15 \mathrm{Mm}^{2}$ in 2017 (He et al., 20I9). More than 15 national codes for modern wood-framed building including design, construction, acceptance criteria, fire protection, anti-corrosion norms and standards, and technical instruments have been promulgated in the recent decade (Luo and Ren, 20I5). Cross-laminated timber (CLT) is a new generation low-carbon building material suited for prefabricated buildings for which there is a big push in China (Li et al., 2019). Yet, its use is still rather uncommon in China, and concrete and steel have cost advantages against wood. Due to the lack of timber in China, the use of bamboo for CLT in combination with wood might also prove to be an option (Li et al., 20I9).

China is the largest textile producer, consumer and export country in the world. The production volume of manmade chemical fibres for textiles was 49 million tonnes in 2017 in China and accounted for over $70 \%$ of global production. China produced 28.7 billion clothing items in 2017 , amounting to almost seven items for every person on the earth (Textile net, 20I8). China still has very little production capacity for Lyocell and Tencel (45000 t/y) fibres that can be made from bamboo or wood, while demand for these fibres in China has been projected to increase to I million in just a few years (Textile net, 20I8).

China is also the largest plastic producing and consuming country in the world. It is producing almost all the plastic it consumes, and it is also exporting some of its production. Every year, 200 billion plastic bottles are used, of which only around $25 \%$ are recycled. This demonstrates the large potential to increase plastic recycling in China. At the same time, the roadmap against plastic pollution (NDRC, 2020) provides clear incentives to replace plastic by other biodegradable materials, including products made of paper and paperboard.

China is the world's third largest producer of liquid biofuels. Its current production of bioethanol is largely based on food crops: corn and wheat (Qin et al., 20I8). Food security issues have been a bottleneck for any further increase in bioethanol production in China. Recently, a Chinese company established corn-ethanol production in the $\mathrm{EU}$, in Hungary (Renewables Now, 2015). However, China should have huge potential for expanding its biofuel production by using agricultural waste and other non-food crops as feedstocks, including poplar and willow (Qin et al., 20I8). Wood pellet production has also increased rapidly in China making it, according to Bioenergy Europe (2020), now the largest producer in the world. China also exports pellets. However, the statistics regarding pellet production in China are very unreliable as the market is supplied by numerous small producers.

\subsubsection{Forest products imports and trade between the EU and China}

China's imports of roundwood, sawnwood, and pulp have increased rapidly since the year 2000 (Fig. 5). China's domestic roundwood production has increased by only $7 \%$ from 2000 to 2019 , while imports of roundwood have almost tripled. In 20I9, China's roundwood imports of $6 \mathrm{I} \mathrm{Mm}^{3}$ accounted for $42 \%$ of the world total roundwood imports (FAOSTAT, 2020). This increase has taken place at the same time as forest land in China has increased more than anywhere. China has prioritised the ecological and social function of forests and used its vast and rapidly growing forest resources sparingly for wood production. However, as the majority of the current plantations are fast-growing monocultures, mainly serving the pulp and paper industry development, China has been very much relying on imported raw materials to support its construction, furniture and wood flooring industries.

China was also the world's largest importer of pulp, veneer sheets and recovered paper in 2018 (FAOSTAT, 2020). The imports of recovered paper to China have been decreasing since 2012 due to the implementation of restrictive regulations aimed at improving the quality of the imported wastepaper (Shang et al., 2020). In particular, the most recent waste import restriction policy from 2017 (General Office of the State Council, 20I7) has resulted in a radical decline in recycled paper imports (Fig. 5).

China has become a net exporter of plywood. Plywood exports from China to the $\mathrm{EU}_{27}$ in $20 \mathrm{O} 7$ (about I.5 $\mathrm{Mm}^{3}$ ) comprised roughly $23 \%$ of the EU's plywood imports or apparent consumption, and I3\% share of the Chinese total plywood exports (FAOSTAT, 2020).

The total value of Chinese forest products exports was roughly I2.7 billion EUR and the respective value of imports was roughly 48 billion EUR in 2018 (FAOSTAT, 2020). These statistics exclude the value 
of the trade of wooden furniture and some other finished wood-products.

The share of paper and paperboard products in the value of forest products net exports from the EU to China was still $60 \%$ in 2000 , but by 2017 it had dropped to $21 \%$. The respective share of wood pulp has increased from $4 \%$ to $48 \%$ in the same period
(FAOSTAT, 2020). Roundwood exports from the EU to China have also increased (Fig. 6). These developments indicate that the EU has decreased its more valued added exports and increased its less value-added exports to China.

The export volume of softwood sawnwood from the EU to China was circa 2 million $\mathrm{m}^{3}$ in 2017.

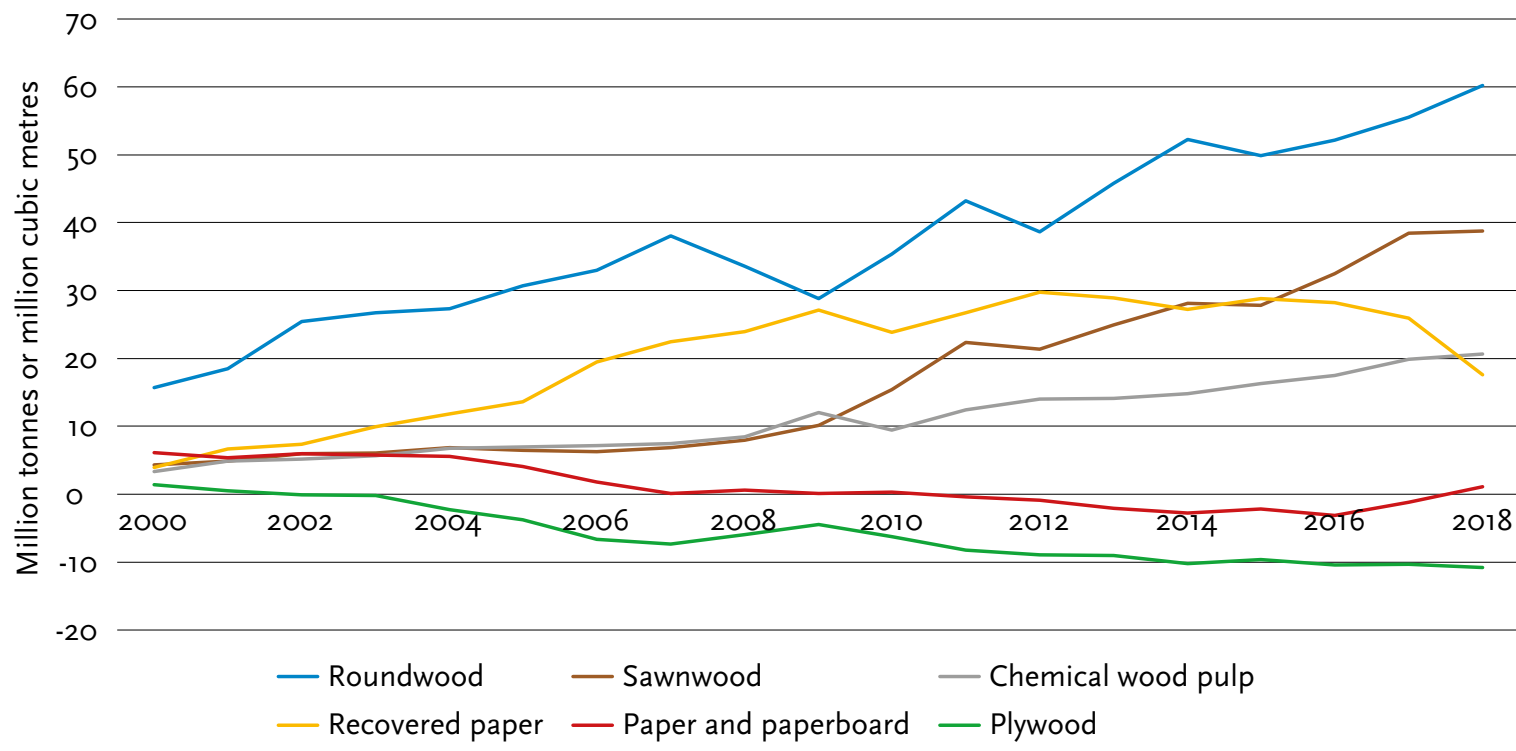

Figure 5. Chinese net imports (imports - exports) of selected forest products from the rest of the world. For recovered paper, pulp, and paper and paperboard the figures are in million tonnes. Else, the unit is in million cubic metres. Negative net imports indicate that China has exported more than imported. Source: FAOSTAT (2O2O).

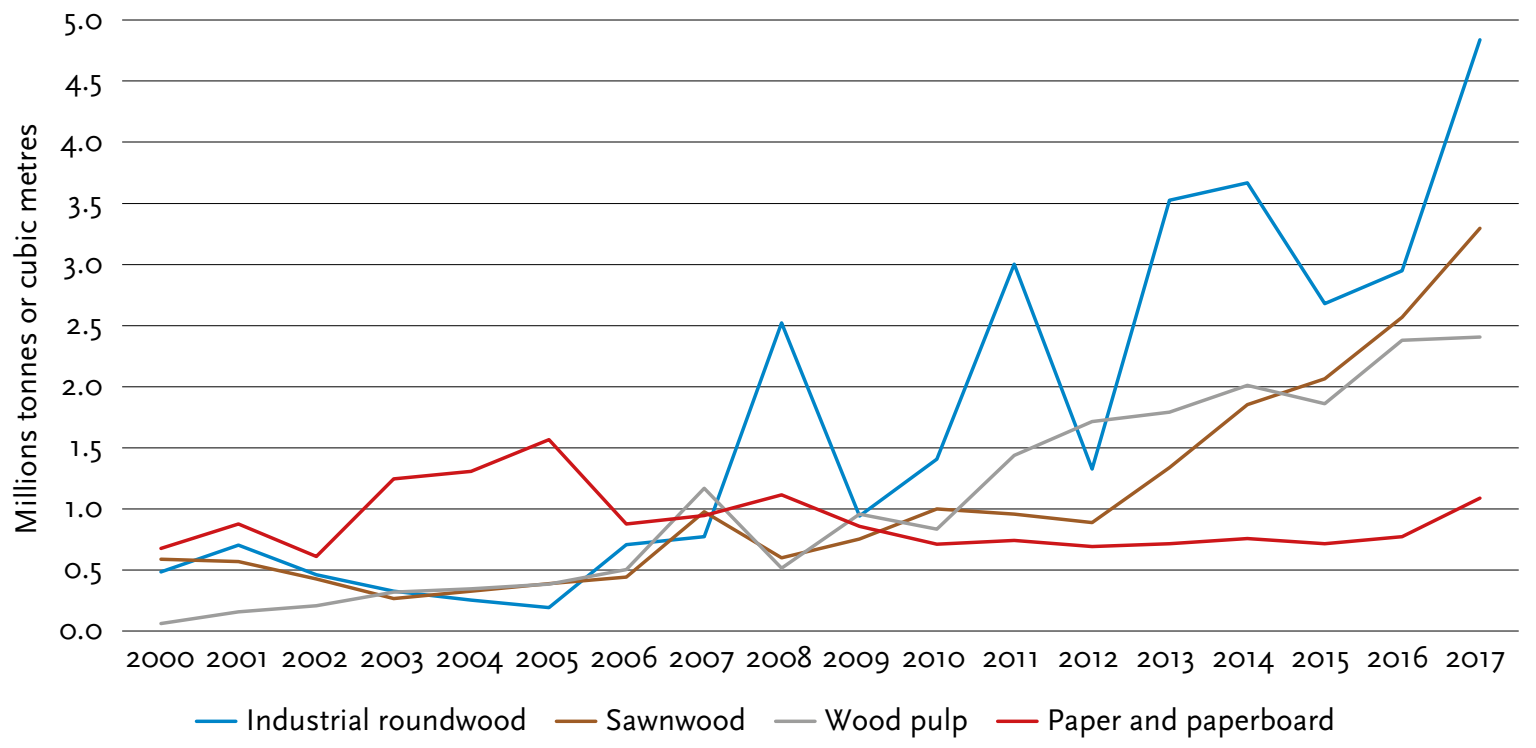

Figure 6. Volume of exports of selected forest product from the EU-27 to China. For recovered paper, pulp and paper and paperboard the figures are million tonnes. Elsewhere, the unit is million cubic metres. Source: FAOSTAT (2020). 
While the volume has grown considerably, it still accounted for less than $8 \%$ of Chinese imports of softwood sawnwood in 20I7 (FAOSTAT, 2020).

Europe is a net importer of higher value products such as wooden flooring and wooden furniture from China. Chinese exports of wood furniture to the EU grew rapidly until it peaked in value in 2008 , showing a stagnating trend thereafter. This could reflect the, at times, painstaking measures of Chinese enterprises to ensure that their products meet the requirements of the EU Timber Regulation (Forest trends, 20I7), in addition to the general trend of more of the production being consumed domestically in China.

Europe is a net exporter of important raw material for wood-based textile fibres: dissolving pulp. The EU's exports to the world's biggest consumer country, China, have increased, and in 2018 they made up almost one third of EU dissolving pulp production.

The above developments reflect the more general pattern of China increasing its imports of primary or bulky wood products and developing its own industry for processing the materials to finished products. While the value added of the Chinese forest industry exports can still be regarded as on the low side in international comparison, it has been improving in the last decade (Su et al., 2020).

\subsubsection{The foreign investments between China and the EU in the bioeconomy context}

China's outward foreign direct investments (ODI) have increased rapidly since 2000 , following the "Go Global" strategy, an effort by the Chinese government to promote investments abroad (Fig. 7). By 2018, China's outward ODI stock, including investments into Hong Kong, had grown to roughly r.8 trillion EUR accounting for $6.4 \%$ of the global total ODI stock (Ministry of Commerce, 20I8).

China's investments into the EU have fluctuated strongly (Fig. 8). Business acquisitions included in these investments vary a lot from year to year depending on the size and location of the acquisition targets. The investments have supported China's aim of acquiring technological knowhow, brands and international property rights on which to build further technical development. The investments have also led to technical upgrades in European companies (Drahokoupil, 20I7). Three EU-27 countries (Netherlands, Luxemburg, Germany) had more than Io billion USD China FDI stock by 2018 (Ministry of Commerce, 2018).

There have been only few forest bioeconomy-related investments by Chinese actors in the EU (Seaman et al., 20I7). During the recent years (after 2015 mainly), several forest biorefinery projects with finance coming from Chinese companies have

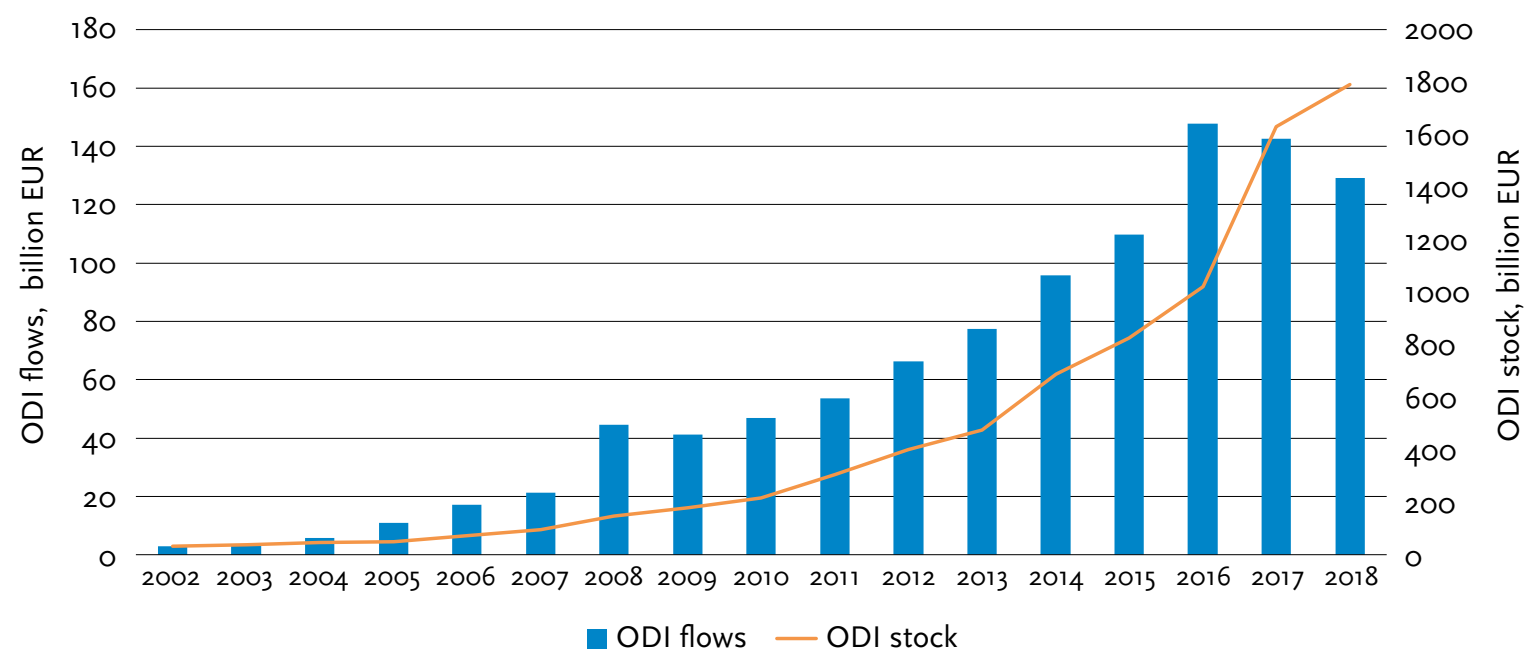

Figure 7. Chinese ODI flows and stocks in 2002-2018, globally (billion EUR). Source: 2018 Statistical Bulletin of China's Outward Foreign Direct Investment. 


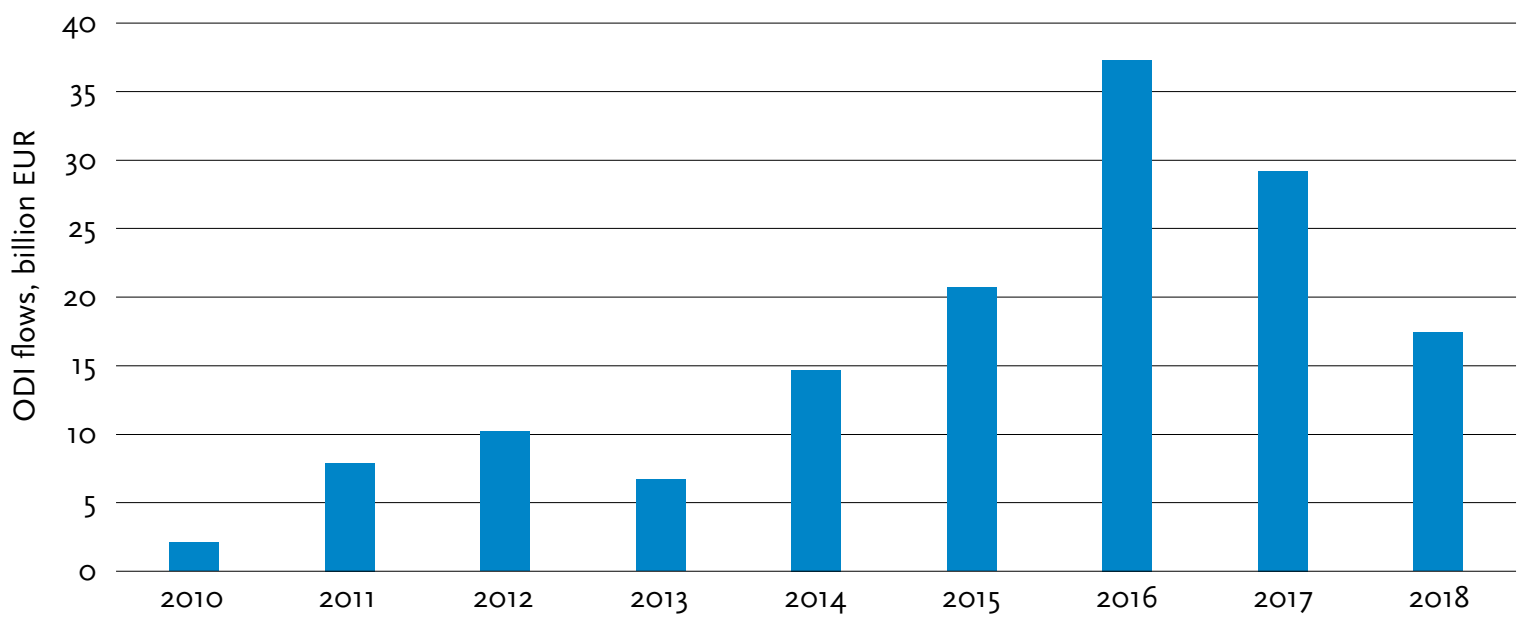

Figure 8. China's ODI flows and stock into the EU-28 countries, 2010-2019 (billion EUR). Data source: Merics report by Krazt et al. (2020, page 9) based on Rhodium Group.

been proposed, eg into Finland. While some of the projects have proceeded to the planning phase, engaging consulting services, no important projects have advanced to the construction phase so far. The majority of the greenfield forest biorefinery investments in the EU have been carried out by European companies and capacity has largely remained in European ownership. Furthermore, with regard to traditional forest industry, only I4 out of I300 enterprises under non-EU ownership producing wood and wood product products in the EU (excluding furniture) were controlled by Chinese companies in 2017 (Eurostat, 2020a); nine of them located in Romania. Only five paper and paper product manufacturers were under Chinese operation, three of them in Sweden (Eurostat, 2020a). In terms of valued added, the paper companies were four times more important than the wood and wood product companies (Eurostat, 2020a). The market presence of some big European forest industry companies in China, eg Stora Enso and UPM, suggests that the European companies have invested far more into production capacity and operations in China than the other way around. Considering that in the last 20 years markets have been growing in China while being somewhat mature in the EU, this situation is by no means surprising.

After peaking in 2016 (Fig. 7), Chinese investments have been decreasing globally and the decline in investments into the EU is no exception (Fig. 8). Implementation of regulations on the screening of foreign direct investments in the EU (European
Parliament and the Council, 20I9b) may slow down Chinese acquisitions in the EU further. Instead, R\&D collaboration between Chinese and European entities has increased in recent years and these interactions, aimed at creating novel technologies and know-how, have the potential to bring substantial benefits to the actors involved (Kratz et al., 2020).

Investments from the EU to China are also facing difficulties (Haneman and Huotari, 20I8). OECD (2020) ranks China as the world's sixth most restrictive country for foreign investments. According to an EU Chamber of Commerce in China survey (2019), the market access barriers, regulatory burdens and unequal enforcement hinder investments to China. Despite the challenges, $62 \%$ of survey respondents viewed China as a top three destination for present and future investments. At the end of 2018 , China issued Foreign Investment Law of the People's Republic of China in order to promote foreign investments.

\subsection{Forest resources}

\subsubsection{Forests in the EU}

Forests and other wooded land make up roughly $45 \%$ of the land in the EU-27 and $73 \%$ of it was available for wood supply in 20I5 (Eurostat, 20I8). Sweden reported the largest forest area (28.0 million hectares), followed by Finland (22.4 million hectares) and Spain (I8.6 million hectares) (FAO, 2020). When other wooded land area was also included, the order was Sweden (30.3 million hectares), Spain (28.0 million hectares) and Finland 


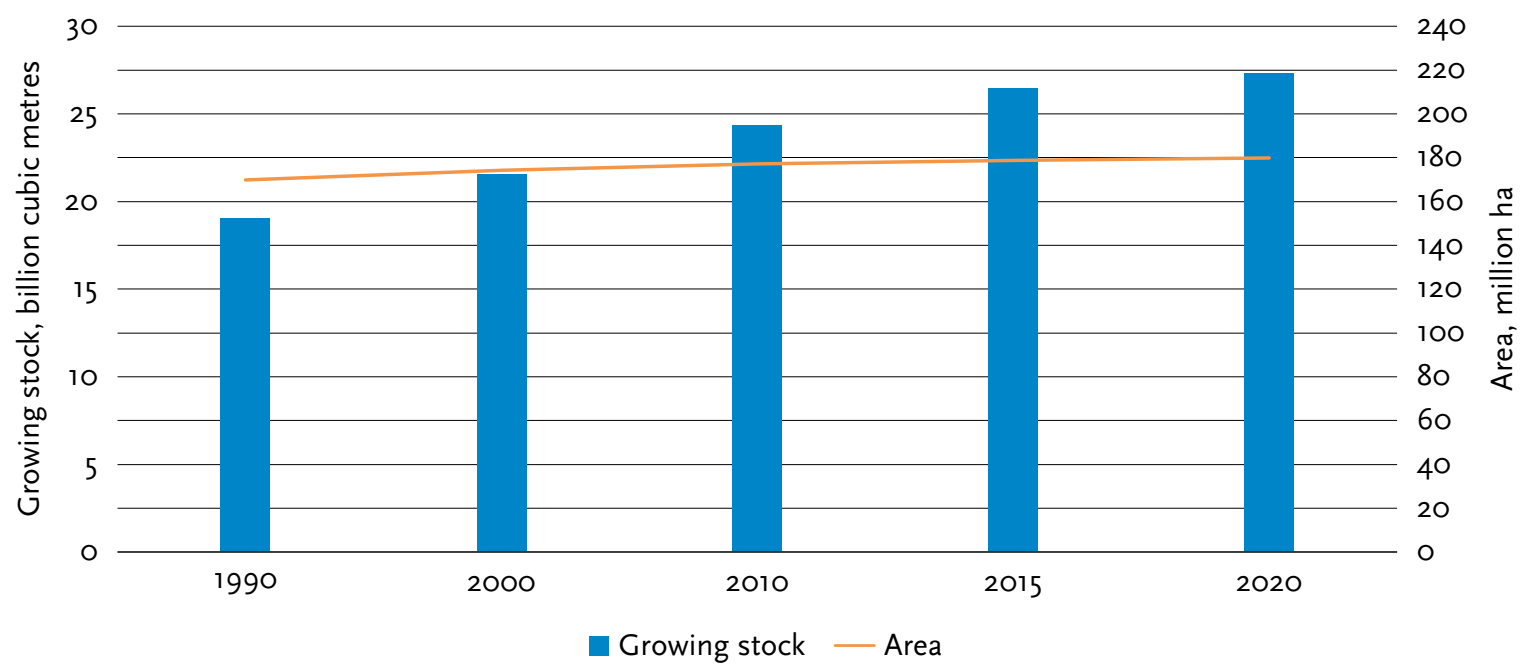

Figure 9. Growing stock of forests in forests and other wooded land (in billion cubic metres over bark) and the size of the respective area (in million hectares) in the EU-27 (excluding Belgium, Malta, Monaco, and Portugal due to missing data). Source: FAO (2020).

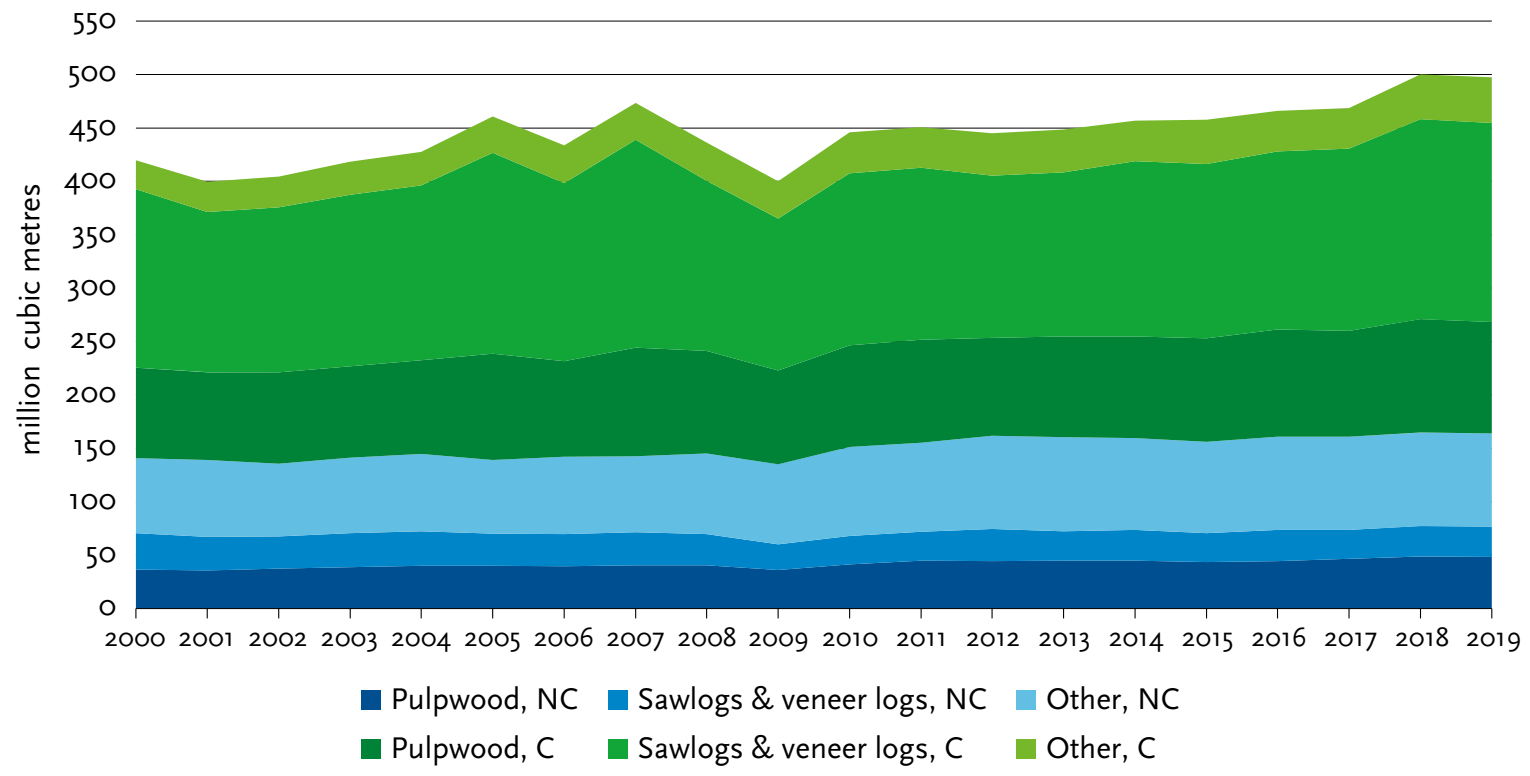

Figure 10. Annual production of roundwood in the EU-27 (million cubic metres under bark). NC=non-coniferous, $C=$ coniferous. "Other" contains mostly fuelwood but also some "other industrial roundwood". Source: FAOSTAT (2020).

(23.2 million hectares). The EU area of forests and other wooded land has increased 6\% from i990 to 2020 (Fig. 9). Urbanisation limits the potential for increasing the forest area.

The forest growing stock in the forests and other wooded land in EU-27 was over 27 billion $\mathrm{m}^{3}$ in 2020 (FAO, 2020, Fig. 9). The top five countries with the highest growing stock (forests and other wooded land) were Sweden $\left(3675 \mathrm{Mm}^{3}\right)$, Germany $\left(3663 \mathrm{Mm}^{3}\right)$, France $\left(3056 \mathrm{Mm}^{3}\right)$, Poland $\left(2730 \mathrm{Mm}^{3}\right)$ and Finland $\left(2456 \mathrm{Mm}^{3}\right)$. The net annual increment, ie the average growth in volume of the stock of living trees available at the start of the year minus the average natural mortality, was estimated at 720 million $\mathrm{m}^{3}$ in the EU-27 in 2010 (the latest reference year available) (Eurostat, 20I8). In the past decade, the harvest level increased more slowly than the net annual increment. Currently, roughly $72 \%$ of the net annual increment is harvested in the EU (Eurostat, 20I8). In 2019, the harvests were estimated to be close to $500 \mathrm{Mm}^{3}$ (Fig. IO, FAOSTAT, 2020). 


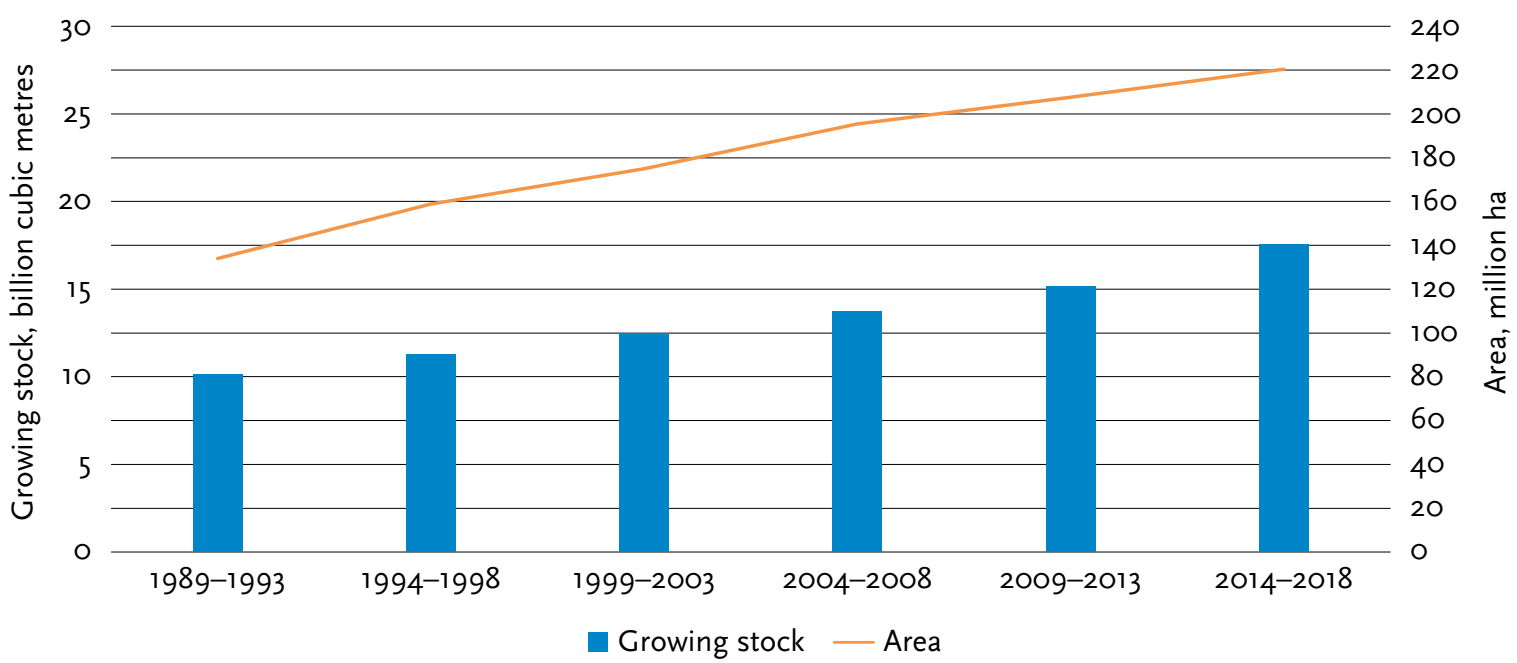

Figure 11. Growing stock of forests (in billion cubic metres) and forest area (in million hectares) in China. Source: NFGA (2019c).

Intensity of forest resources use, measured as the share of harvests of the annual gross increment, has been relatively stable and remained under $80 \%$ in most EU countries. This has allowed the growing stock to increase during the last decades. Occasionally, natural disasters, such as storms and bark beetle calamities, also intensify the use of forest resources, as happened in Central Europe in recent years. An analysis of biomass use and flows in the EU (Camia et al., 20I8) indicates that reported wood removals have been underestimated in some EU countries. In particular, the volume of fuelwood harvests is subject to uncertainties. Data on growing stock development is typically based on national forest inventories and independent of the harvest statistics.

\subsubsection{Forests in China}

China has been increasing its forest cover rapidly and leads the world in afforestation. According to the ninth National Forest Inventory (NFI) for 20I42018, forest area in China has reached 220 million hectares amounting to $23 \%$ of the land area and has a growing stock of $\mathrm{I7} .6$ billion $\mathrm{m}^{3}$ (NFGA, 20I9c). Compared to the eighth NFI for 2009-20I3, forest area increased by 12.7 million hectares and the growing stock (Fig. II) by around 2.27 billion $\mathrm{m}^{3}$. Plantation forest area in China is the highest in the world at 80 million hectares in 2018 .

However, forest quality still needs to be improved in China. Young and middle-aged forests account for $64 \%$ of the forest area. The average growing stock per hectare of $95 \mathrm{~m}^{3}$ (NFGA, 20I9c) is below the world average.

China has implemented a series of natural forest protection projects since 2000 . These were first triggered by the observation of forest degradation and natural disasters, in particular a severe flood in Yangtze river in I998. Initially, 65 million hectares of natural forests were set aside from commercial harvests, covering almost $50 \%$ of the country's natural forests. Because the rest of the natural forests were still facing problems related to, for instance, low quality, fragile ecosystems and serious soil erosion, the Chinese government has banned commercial logging in all natural forests since 2017. This aims to enhance the ecological functions and strengthen the future timber supply capacity of the forests. The natural forest area of 139 million hectares had a growing stock volume of $\mathrm{I} 3.7$ billion $\mathrm{m}^{3}$ in the ninth NFI (NFGA, 20I9c). Hence, almost $78 \%$ of the growing stock of China is under the logging ban.

Most of the harvested roundwood in China now comes from plantations. Plantations not only help to save the natural forests from logging, but they also mitigate land degradation, air pollution and climate change. Currently, most commercial plantations in China produce fast-growing species and only provide small diameter logs. For large diameter roundwood, China will be still dependent on imports for some years. 


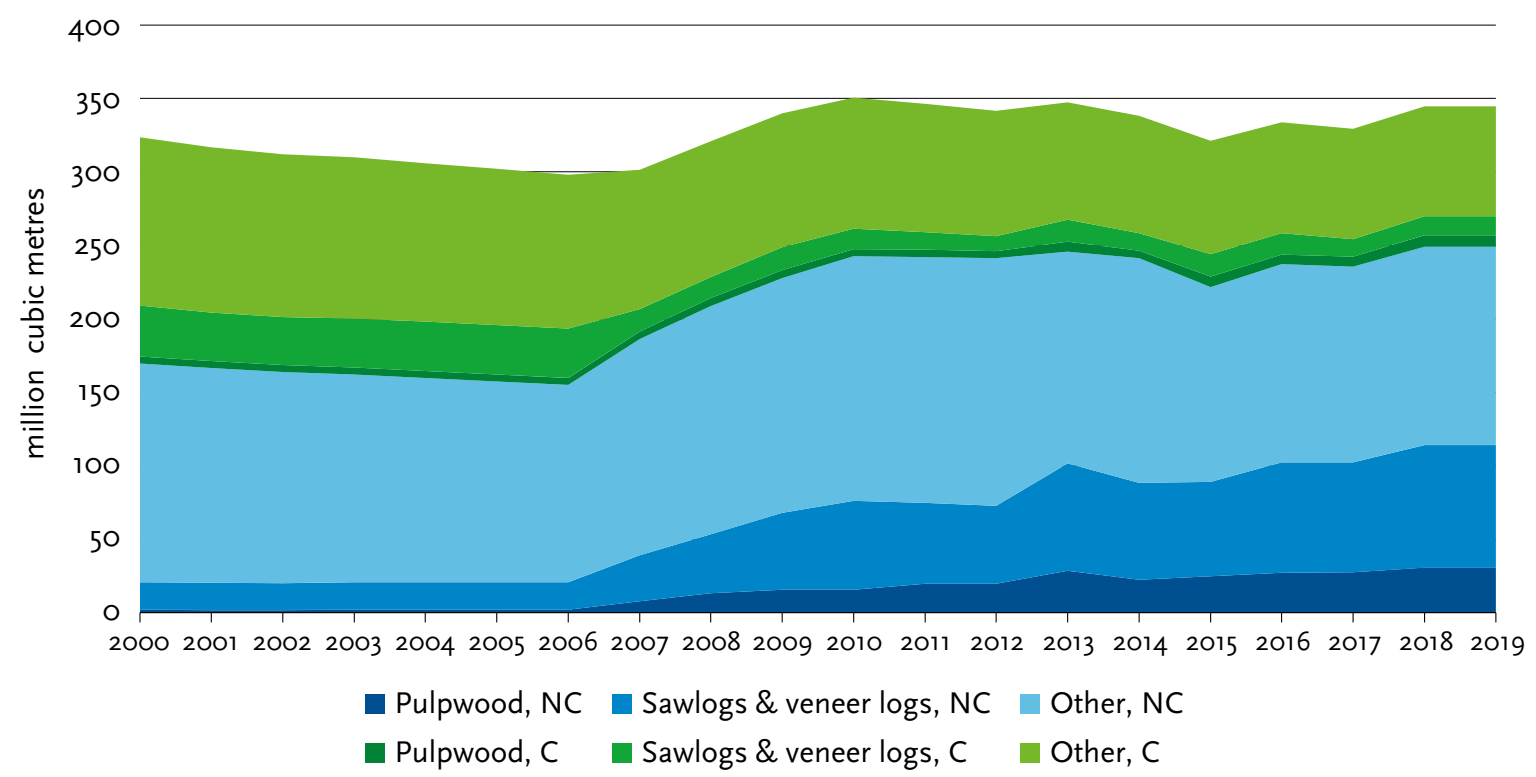

Figure 12. Annual production of roundwood in China (million cubic metres under bark). NC=non-coniferous, $\mathrm{C}=$ coniferous, "Other" contains mostly fuelwood but also some "other industrial roundwood". Source: FAOSTAT (2020).

China has recognised the importance of improving its domestic wood production capacity further. By 2035 , the country aims to have its tree cover raised to $26 \%$ of the land area with $2 \mathrm{I}$ billion $\mathrm{m}^{3}$ of growing stock. The National Reserve Forest Programme (2018-2035) aims to establish some 20 million hectares area of reserve forests with various tree species, including rare ones, various age classes and for multiple functions (NFGA, 20I9a). Importantly, the programme also includes plantations for larger diameter hardwood (usually with rotation of 30 years or more). The programme should provide an average annual net increase in forest stock of 200 million $\mathrm{m}^{3}$ by 2035 (NFGA, 20I9a) and it should also improve the supply of large diameter logs. Of these forests, 7 million hectares were planned to be established by 2020 , including a 2.25 million hectare area of intensive plantations. The programme will provide an important resource base and incentive for China to develop its forest-based bioeconomy.

\subsection{China-Europe bioeconomy cooperation development}

Since the I990s, China and the EU have strived to build a long-term, stable partnership to face global challenges. At the time of the first China-EU summit in I998, stronger bilateral trade and economic relations were the top priorities for the development of the China-EU relation. Coming to the $2 \mathrm{I}^{\text {st }}$ century, China and the EU reinforced cooperation, for example in the fields of science and technology, information, education and human rights.

Since developing a comprehensive strategic partnership in 2003, high-level dialogue and practical efforts between the EU and China have been carried out in the areas of environmental protection and biodiversity conservation. In 2005 , China and the EU issued a Joint Declaration on Climate Change, followed in 2006 by a declaration pointing to sustainable development as one of the major areas for EU-China cooperation. Between 2005 and 2020, a number of joint China-EU declarations and joint statements on the circular economy and low carbon cooperation have been made. Table I summarises the development of the EU-China relationship in this century.

In addition to the cooperation of China and the whole of the EU, China has established forestry cooperation with 16 Central and Eastern European Countries (CEECs) in 20I2. After Greece joined this "I6+I" coordination mechanism in 20I9, it now includes I2 EU Member States. Forestry cooperation belongs to a wider cooperation initiative under the mechanism.

Despite two decades of building the strategic partnership between China and the EU, there are 
still many challenges to overcome. Finding ways to make it easier for EU companies to invest in China is not the only one. For the EU, China is not only a partner for advancing common interest at the global level but also a strategic rival and economic competitor, as taken up in a report by European Commission (2019d). In addition, China's engagement in $16+1$ cooperation mechanisms has not only been seen in a positive light in the EU but has also been viewed as dividing the EU. To avoid friction between the Member States and to advance the EU's interests more consistently, it is better for the EU to negotiate on partnership with China at the unified EU level. Finally, the Covid-I9 pandemic has raised concerns about the EU's over-reliance on China for the supply of strategic goods. Enforcing the reciprocal and mutual benefits of EU-China cooperation will require additional efforts. The recent summit between the EU and China in 2020 stresses that the partners need to have common ground of further strengthening their relations and multilateral cooperation based on trust, transparency and reciprocity in areas of climate change, trade and investment, and green and digital economy. The parties aim to sign the comprehensive agreement on investment in 2020 , and to provide two-way market openness on the basis of equality, mutual benefit and mutual respect for both sides.

Table 1. China-EU bioeconomy cooperation development: cornerstones in brief

\begin{tabular}{|l|l|l|}
\hline Year & Cooperation cornerstones & Actions or highlights \\
\hline 2001 & $\begin{array}{l}\text { Cooperation in areas of environmental } \\
\text { protection and energy }\end{array}$ & $\begin{array}{l}\text { - Started discussion and cooperation in environmental protec- } \\
\text { tion and energy for the first time }\end{array}$ \\
\hline 2005 & A Joint Declaration on Climate Change & $\begin{array}{l}\text { - The establishment of the China-EU partnership on climate } \\
\text { change } \\
\text { - EU agreed cooperation on development and transfer of } \\
\text { low-carbon technology with China }\end{array}$ \\
\hline 2009 & $\begin{array}{l}\text { Promote a low-carbon economy } \\
\text { area of cooperation }\end{array}$ & $\begin{array}{l}\text { - Circular economy was introduced to China by EU for the first } \\
\text { time }\end{array}$ \\
\hline 2012 & $\begin{array}{l}\text { Transition to a low carbon and green } \\
\text { economy }\end{array}$ & $\begin{array}{l}\text { - Research actors and SMEs encouraged to carry out R\&D and } \\
\text { innovation cooperation }\end{array}$ \\
\hline 2015 & $\begin{array}{l}\text { A joint statement on Climate Change } \\
\text { enhanced } \\
\text { International coordination and cooperation on tackling climate } \\
\text { change rose in importance }\end{array}$ \\
\hline 2018 & $\begin{array}{l}\text { Transition to a circular economy as a } \\
\text { priority }\end{array}$ & $\begin{array}{l}\text { To embark on low-carbon development } \\
\text { - To cooperate on developing a cost-effective low-carbon econ- } \\
\text { omy }\end{array}$ \\
\hline $\begin{array}{l}\text { Signing the Memorandum of Understanding on Circular Econ- } \\
\text { omy Cooperation } \\
\text { Adopting the Leaders' Statement on Climate Change and Clean } \\
\text { Energy }\end{array}$ \\
\hline
\end{tabular}




\section{Climate and sustainability policies related to the bioeconomy}

\subsection{Climate and sustainability policies in China}

\subsubsection{Climate change policies}

The path from the 1992 Rio Summit to the Kyoto Conference and further to the 20I5 Paris Agreement in the global climate policy negotiations has not been an easy one for China. As the world's second largest economy and largest greenhouse gas emitter, currently with a nearly $30 \%$ share of global emissions, China has been in the spotlight, facing great pressure in the process of participation and implementation of international climate change conventions. In 2005, China's greenhouse gas emissions without the land use sector were $8.0 \mathrm{Gt} \mathrm{CO}_{\text {eеq }}$, and by $20 \mathrm{I} 4$ they had risen to $\mathrm{I} 2.3 \mathrm{Gt} \mathrm{CO}_{\text {zeq }}$ (UNFCCC, 2020). These figures are, however, subject to large uncertainty (Shan et al., 20I8). The emissions are still growing but should reach their peak by the end of this decade.

Modifying energy structures to reduce the energy and carbon intensities per unit of GDP is a high priority area in Chinese climate policy. Within the plan for 2016-2020, China had a target to reduce the carbon intensity of the economy, ie the $\mathrm{CO}_{2}$ emission per unit of GDP, by $50 \%$ from the 2005 levels by 2020 . That target has been reached (Ministry of Biology and Environment, 2019) and China is also expected to complete its target of having $15 \%$ of its primary energy consumption coming from non-fossil energy sources in 2020. In its first national commitment to the Paris Agreement (Department of Climate Change, 20I6), China announced its determination to peak its $\mathrm{CO}_{2}$ emissions around 2030, to lower the carbon intensity of the unit of GDP to $60-65 \%$ of the 2005 level, to increase the share of non-fossil fuels from primary energy consumption to $20 \%$, and to increase the growing stock of forests by 4.5 billion $\mathrm{m}^{3}$ by 2030 compared to 2005 . In September 2020, China's president Xi Jinping stated in his speech at the $75^{\text {th }}$ Session of the UN General Assembly that China will strive for carbon neutrality before 2060 .

The development of clean energy to address climate change mitigation and combat air pollution is an important technological innovation area for
China. Consequently, hydro, wind, solar and nuclear power are increasingly important non-fossil energy sources in China. Share of renewable energy sources in final energy consumption in China was close to $13 \%$ in in 2016 (IRENA, 20I8) and China was the leading country in installed capacity and generation of solar, wind and hydro power in 2019 (IRENA, 2020). Moreover, several actions relevant to the circular forest-based bioeconomy are mentioned in the first nationally determined commitments by China to the Paris Agreement. These include, for instance, promoting the reuse of agricultural and forestry waste, recycling building waste, improving the waste separation and recycling systems, promoting green buildings, increasing the growing forest stock, and strengthening forest infrastructure and carbon sinks. The tree plantation programmes and the ban on logging in natural forests have contributed to the increase in the forest carbon sink in China. The tree plantation programmes also provide large potential for enhancing the sustainable resource base for forest bioeconomy.

China has seven regional carbon markets and it is preparing to launch a nationwide Emissions Trading System (ETS) covering 6 Gt of emissions annually (Ma et al., 2020), which is by far the largest ETS in the world. Thermal power producers would be first to enter the system. China has also set targets for biofuel production. For 2020, the national fuel ethanol production target was Io Mt/yr (Qin et al., 20I8).

\subsubsection{Sustainability policies}

Over time, China has carried out a series of actions to restructure its economy and transform its development patterns by eliminating overcapacity, promoting the development of strategic and emerging industries and upgrading traditional ones. A series of laws and regulations have been promulgated, implemented and amended in accordance with the requirements of sustainable development strategy. In 20I2, China published its first national report on sustainable development, documenting the efforts and progress since 200I (China Preparatory Committee, 20I2). Sustainable development goals 
were found to have been advanced eg in areas of poverty alleviation, boundaries of natural ecological environment, resource constraint and economic and social structural problems.

By the end of 2015, China had taken steps towards ensuring environmental sustainability, and further efforts were taken to reduce biodiversity loss by 2020 . In 20I5, China endorsed Transforming Our World: the 2030 Agenda for Sustainable Development and integrated it into the thirteenth FYP and other mid- and long-term development strategies. Key policy targets include the adoption of a sustainable consumption and production model (SDG Goal I2), the protection, recovery and promotion of sustainable use of ecological land systems, sustainable forest management, prevention of desertification, and halting land degradation and biodiversity loss (SDG Goal I5). A progress report on implementation of the agenda was published in 2019 (Ministry of Foreign Affairs of China, 20I9).

\subsection{The EU's climate and sustainability policies}

The greenhouse gas emissions of the EU-27 without the land use sector were 21\% below their I990 level in 2018 (Eurostat 2020b). Thus, the EU still has a lot to accomplish in order to reach its commitment to the Paris Agreement of an emission cut of $40 \%$ by 2030 , and even more, to make it to $50 \%$ as proposed in the EGD. The 2030 climate and energy framework - EU-wide targets and policy objectives for the period 202I-2030 - comprises a binding renewable energy target for the EU for 2030 of at least $32 \%$ of final energy consumption, including a review clause by 2023 for an upward revision of the EU level target. Moreover, the LULUCF regulation aims to maintain and strengthen the forest carbon sinks of the Member States.
The European Green Deal (EGD) would include reviews of the Renewable Energy Directive, the Energy Efficiency Directive, and the LULUCF regulation in order to align them with the new climate goals. It is not yet possible to ascertain what would be the outcome of such reviews. Would there, for instance, be changes to the acceptable feedstock for advanced biofuels? Currently, the revised EU renewable energy directive promotes the transition from first generation biofuels to advanced biofuels not competing directly with food and feed crops (European Parliament and the Council, 20I8b). The EGD also foresees at least a doubling of current rates of renovation of public and private buildings (European Commission, 20I9b). It also proposes the development of a power sector based largely on renewable resources (European Commission, 2OI9C).

The EU Timber Regulation (EUTR) sets obligations on operators who place timber and timber products on the EU market in order to counter the trade in illegally harvested timber and timber products in the EU (European Parliament and the Council, 20Io). This is likely to affect the trade of wood products from China to Europe even more in the future. Since the growing forest-based industries in China are increasingly using imported roundwood, the risk of products, for instance furniture, being made of illegally harvested roundwood is also growing (UNEP-WCMC, 20I8). So far, there are no studies considering if, and in what respects, the EUTR, in particular, has already affected the wood imports of China. Nevertheless, to comply with the EUTR, Chinese imports of roundwood from safe sources should increase. In the Bilateral Coordination Mechanism, China and the EU work together to reduce illegal logging and promote legally sourced timber and timber products (EUFLEGT, 2019). 


\section{Outlook for China-Europe forest bioeconomy development to 2030}

\subsection{Key factors influencing forest- based bioeconomy development}

Economic development, demographics, technological progress, policies and consumer preferences are important generic drivers of market change (Jonsson, 2013). In addition, geopolitical developments, development of forest resources (see eg sections 2.4.I. and 2.4.2) and climate change influence the development of the forest-based bioeconomy in China and the EU. Since bioeconomy calls for smarter, circular use of biological resources, often in new business areas, social and technological innovations are crucial in the transformation process. Together with policy interventions, they enable the departure from business as usual economic development. Figure i3 summarises key factors influencing future forest bioeconomy developments in the
EU and China and the interaction between the two regions.

\subsubsection{Economic growth}

Economic growth is an important driver for demand for most forest-based products and services, even though the material resource intensity of GDP growth may decline over time (Palahí et al., 2020). During 2000-20I8, the Chinese economy grew on average $9 \%$ pa and the GDP per capita more than quadrupled. In the EU, the real GDP growth was around $2 \%$ at the same period (World Bank, 2020). Since 20I4, the GDP growth in China has been slightly lower, 7\% pa (World Bank, 2020), and it had been forecast to remain below $7 \%$ in this decade. The outbreak of the Covid-I9 pandemic in 2019 and its drastic social and economic consequences have increased the uncertainty in any future outlooks

\section{Political}

- Strategies supporting circular bioeconomy

- Commitment to address climate change and implement SDGs

- EUTR implementation in the EU

- Changing policies (eg EGD, RES, LULUCF, forest laws and programmes in China) create uncertainty on eg availability of wood and on supported uses of biomass

- Geopolitics, eg trade wars

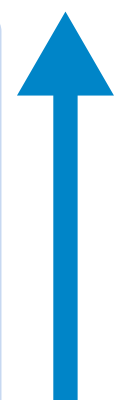

Economic

- Economic growth in China (lower than in the last decade, but possibly still high even after Covid-19 crisis)

- Mature markets for traditional forest sector products in the EU

- Supportive financial and public procurement policies in China

- Supportive monetary policy
Social

- Ageing of population (continues)

- Urbanisation (continues)

- Growth of educated middle-class in China (continues)

- Consumer preferences for green products (possibly strengthening)

- Demand for ecological and recreational functions of forest (may increase)

- Change in consumer behaviour for using less resources (desired)
Technological and social innovations

- Bio-refineries for textiles, nanomaterials, lignin applications and substitutes for non-degradable plastic packaging

- Wood-based construction \& new product innovations

- Recycling and turning "waste to value"

- Nature-based health services, recreation \& tourism

Figure 13. PEST chart of factors influencing forest bioeconomy development in the EU and China. Source: Authors. 
for the global GDP growth. In June 2020, the International Monetary Fund (2020) estimated that the world output might contract by $4.9 \%$ in 2020 and possibly recover with a $5.4 \%$ gain in 202I given supporting policies and fading out of the pandemic. For China, it forecast I\% real GDP growth for 2020 and $8.2 \%$ for 2021. The pandemic is expected to cast its shadows over economic development for the rest of this decade.

\subsubsection{Demographics}

Population growth increases the demand for forest products directly (more consumers) and indirectly by promoting economic growth. Changes in the age structure of the population, urbanisation and the growing share of the middle-income group affect the demand for products and services. An increasing old-age dependency ratio tends to decrease residential construction volumes (Lindh and Malmberg, 2008). In China, the ratio of people older than 64 to those aged $15-64$ is projected to increase from $15 \%$ in 2018 to $25 \%$ by 2030 (United Nations, 20I9). The respective ratio in the $\mathrm{EU}$ was around $30 \%$ in 2018 (World Bank, 2020) and it is forecast to be $40 \%$ in 2030 (Eurostat, 2020). At the same time, ongoing urbanisation increases the overall housing demand, but it changes the type of housing constructed. It slows down the growth in residential construction in rural regions, while promoting demand for new housing in urban regions. Share of urban population in China is projected to increase from some $60 \%$ in 2018 to $70 \%$ by 2030 , which roughly follows the earlier pace of increase in urbanisation.

\subsubsection{Technology and new products}

For the relatively short time horizon considered in this report, progress in the fields of biotechnology, manufacturing, and material circulation are the most important for the forest-based bioeconomy.

The recent decade has already seen the development and market breakthrough of modified woodbased construction materials that are lighter in weight, more durable, or less harmful to the environment compared even to the traditional wood products (Heräjärvi et al., 20I9). These include, for example, cross laminated timber (CLT) and laminated veneer lumber (LVL) that can replace hollow concrete slabs, insulation materials made from, for example, recycled paper or wood chips that can replace rock or glass wool, and thermally modified timber products suitable for various applications from furniture to outdoor constructions. Wood-based nanoscale materials can be scaled to be used in various consumer segment applications, like cars and bikes, but also in construction. Development is going on in many other areas as well, such as in making biodegradable wood-based substitutes for plastics which can be used in existing packaging value chains (Paptic, 2020; UPM, 2020; Sulapac, 2020). Production and recycling of textiles is also experiencing several innovations, including mechanical spinning of cellulosic fibres into textile yarn without chemical treatment (Spinnova, 2020), making textiles from various materials, including old textiles and paper using recyclable process solvent (Ioncell, 2020), or separating cotton from recycled textiles and combining that with cellulose from wood to make new dissolving pulp (Södra, 2020).

Many of the emerging wood-based products, including valuable chemicals, can be produced from by-products of other forest industry products or from end-of-life wood and wood-biomass based materials (Hurmekoski et al., 20I8, 2020; Routa et al., 20I7). These products complement the set of opportunities for forest-based industries for obtaining value from production side streams, and of course, are strongly in line with circular use of resources.

\subsubsection{Policies in the EU and China}

Several policy initiatives support or hinder the transformation to bioeconomy. Many of them have been discussed earlier and here we summarise just some of these based on their impact area. See also Figure I4.

\section{Policies promoting efficient use of materials}

In the EU, the legislative framework on waste enforces increased recycling of municipal waste including paper, textiles, wood materials, and packaging waste by 2030 . It has been estimated that around 600 million tonnes of waste materials that could potentially be recycled or reused go to waste annually (European Commission, 20I8b).

\section{Policies affecting the use of forest resources}

China has banned the logging of natural forests, but also implemented massive tree plantation programmes. The Fast Growing and High Yield Plantations programme (2000-2010) has already increased the supply of small diameter logs. One of 


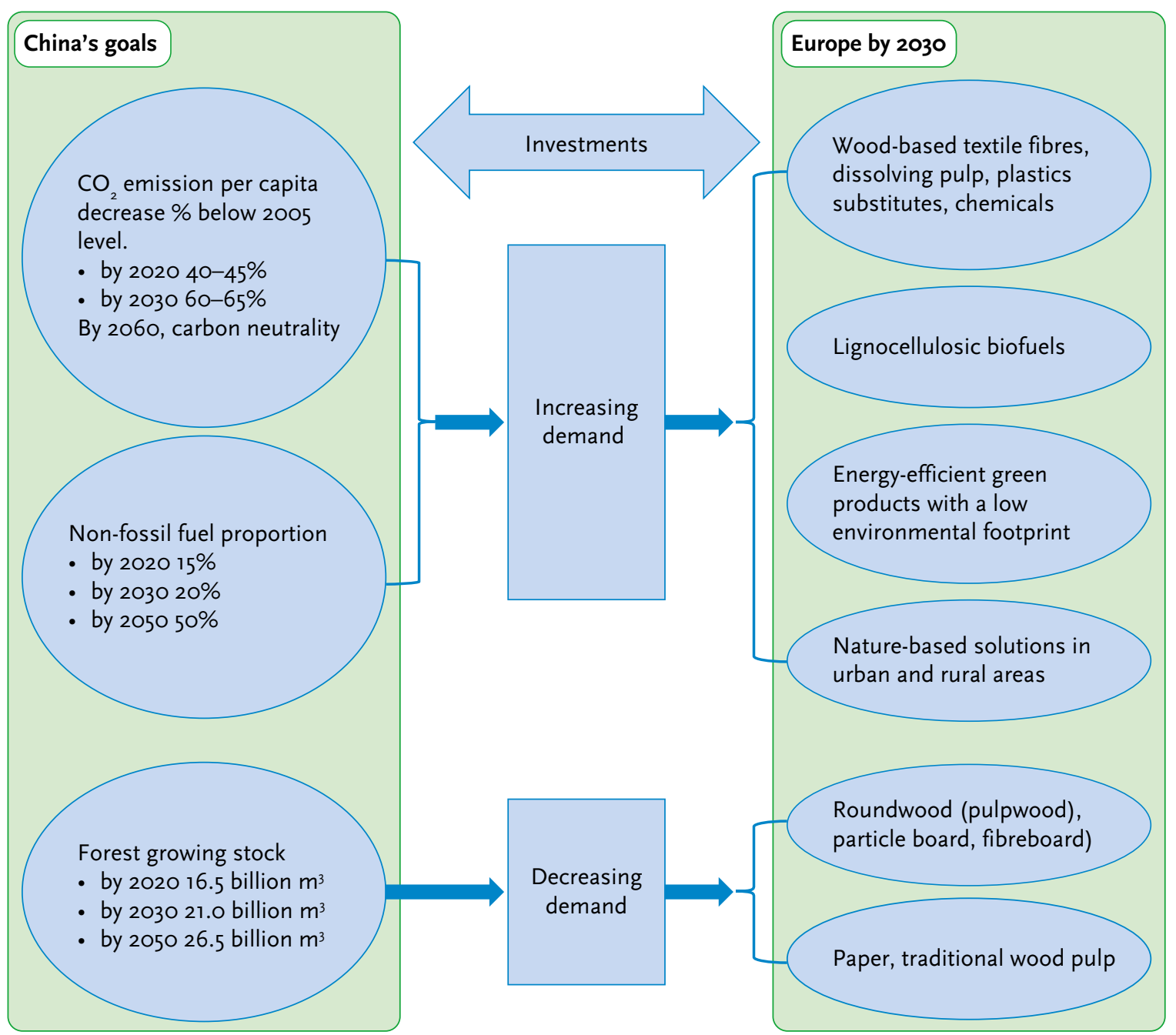

Figure 14. Impact of the climate change and sustainability related policies of China on forest bioeconomy industry in Europe by 2030 compared to "business as usual" without the policies. The Chinese goals after 2030 are for additional information. Sources: Edited by authors.

the aims of the National Reserve Forest programme (2018-2035) is to increase the supply of large diameter logs, particularly those of hardwood. While it is likely to take more than a decade to show in the sawlogs supply, the programme should further increase the supply of pulpwood in this decade.

In the EU, there is some room for increasing the wood supply even in the frame of the forest reference levels submitted by the EU Member States to the EU. The European Green Deal may tighten the LULUCF regulation and it may also bring in new restrictions on the use of forest land in order to safeguard forest biodiversity. That could potentially restrict the supply of domestic virgin wood fibres in the EU in the coming decade, and possibly lead to some leakage of production of forest products from the EU to the rest of the world (Kallio et al., 20I8). These policies strengthen some of the sustainability aspects of the forest-based bioeconomy but weaken some others. The EU framework on waste, on the other hand, can be expected to prolong the lifetime of materials already in use, and thus decrease the demand for virgin wood fibres.

Policies affecting the consumption of forest biomass and forest products

In the EU, the EGD foresees a doubling of renovation activities, providing potential market options for wood-based materials in the EU. It also proposes development of a power sector based largely on renewable resources (European Commission, 20I9c), and it may come to regulate the use of roundwood 
for energy. Several Member States will abandon the use of coal by 2030 , which would reduce the demand for pellets in co-firing. Even if the replacing energy comes from biomass-fired thermal energy units, those could often use wood and other biomass in more diverse forms than pellets.

China's climate and sustainability goals and several policies that promote green, low carbon and circular economy development and technology innovation have already provided markets for green products and clean technology. As many of the laws, regulations and guidelines are very recent or just waiting for their implementation, there should be considerable further market growth for products and services that could be provided by the forest bioeconomy. This requires green investments and also creates market opportunities for EU producers of clean technologies, services and bio-based products. Despite the continuous increase in the use of clean energy forms in China, the country will still largely rely on fossil fuels in 2030. Thus, the GHG substitution benefits provided by replacing carbon intensive products by wood products, eg in construction, will remain important. China has also set policies favouring wood-based construction. Moreover, the recent roadmap against plastic pollution should create demand for wood-based substitutes for plastics in several application areas. Finally, to increase the share of non-fossil fuels in its energy mix further, China might also increase its use of wood pellets in industrial scale.

Policies affecting the trade in forest products between China and Europe

The development of the trade relations between China and its big trading partners, such as the US, Canada, Australia, and Russia will have large impacts on EU-China trade (see also 4.I.7). In addition, the European Timber Regulation and laws in other countries that try to curb the illegal logging of forests, including the updated forest law in China, may become stricter in their implementation. That would increase the cost for enterprises in China (though not only there), because the roundwood prices would go up due to more competition over roundwood from legal origins (Moiseyev et al., 20I0) and because enterprises would need to comply with the requirements for documentation of wood sources.
Policies affecting investments

China uses green financing, eg green bonds and green credit, to help meet its climate policy goals. Green bonds are regulated and guided by policies, including PBoC's Guidelines for Establishing the Green Financial System (2016), NDRC's Guidelines for Issuing Green Bonds (2015) and the China Securities Regulatory Commission's Guidelines for Supporting Green Bond Development (20I7). These bonds, issued by commercial and governmental banks and corporations, reached a value of around 37 billion dollars in 2017 and provided funding, for instance, to solar and wind power, low-carbon transport, hydro projects, and the replacement of small coal plants with cleaner and more efficient ones (Sandalow, 20I8). Funding coal energy is not accepted in leading international standards for green financing, which hinders the market participation of international green investors. Chinese decision makers have recently started to consider eliminating coal plant projects from the green- bond standards. That would increase the participation of international investors.

\subsubsection{Consumer preferences}

China's economic growth has raised environmental and health concerns among its citizens and boosted 'green consumerism'. Awareness of green products has increased among Chinese consumers, who are concerned about visibly unfavourable changes in their environment as well as possible health-related safety risks (Zhu and Sarkis, 2oI6; Wan and Toppinen, 20I6)

European consumers seem to consider it less important that the material is renewable but rather focus on "recyclability" and "degradability" (Herbes et al., 20I8). That tendency may strengthen when consumers are increasingly affected by the EU waste legislation. In China, green consumers focus most attention on energy, water, and cost savings, or organic and green chemicals usage in green products (Zhu and Sarkis, 20I6).

Regarding wood construction, consumers have been found to be worried about the fire safety of wood (eg Gold and Rubik, 2008). Furthermore, the path dependencies related to the knowhow and use of eg concrete by the construction industry may hamper wood construction development in China, as Toppinen et al. (2019) have found in Europe.

Environmentally conscious consumption behaviour has the potential to shape global clothing markets. 
According to the Ellen MacArthur Foundation (2018), the average number of times a garment is worn decreased globally by $36 \%$ from 2002 to 2017 . In China, the respective decrease was even higher, more than $70 \%$. Material use and reuse in the clothing industry is one of the fields calling for solutions from sustainable, circular bioeconomy.

\subsubsection{Forest disturbances}

Climate change is increasing the frequency and intensity of forest disturbances caused by insect outbreaks, invasive species, wildfires and storms (eg Seidl et al., 20I7). These disturbances, which are difficult to anticipate, can have strong short-run market impacts. The recent bark beetle infestation in Central Europe, which was coupled with changing climate conditions, is a prominent example. It damaged over $270 \mathrm{Mm}^{3}$ of standing timber between 2017 and 20I9 (Taylor, 2020). That caused salvage logging and temporarily increased European exports of spruce roundwood to China. Chinese forests are not immune to the disturbances either. In particular, monoculture tree plantations have been found to be vulnerable to pests and disease (see Liu et al., 20I8).

\subsubsection{Geopolitics}

Geopolitics can have immediate effects on all economic sectors. As a 'wild card', it has the potential to disrupt prevailing trends. Trade wars are an example of such possible game changers in bioeconomy development. For instance, the trade war between China and the United States, which escalated in 20I8, has decreased Chinese sawnwood imports from the US. That has affected other regions through trade diversion.

In the global policy arena, particularly trade developments related to China, Russia and North America, for example, will have important implications for the European forest sector (Wolfslehner et al., 2020). In September 2020, Russia announced a plan to ban all its foreign exports of unprocessed or lightly processed coniferous roundwood and valuable non-coniferous roundwood from 2022. Over $80 \%$ (some $9.5 \mathrm{Mm}^{3}$ ) of the Russian coniferous roundwood exports went to China in $20 \mathrm{I} 7$ (FAOSTAT, 2020). Hence, the policy would affect China, in particular, as it suffers from a supply shortage of domestic coniferous roundwood species.
In the EU, the possibility of setting a carbon tax on imported products from highly pollutive industries, like concrete or steel, is being discussed as a part of the EU's Green Deal. If implemented, the risk for trade disputes between the EU and its trading partners could increase. Finally, the Covid-I9 crisis may lead to increased regionalism at the expense of globalisation.

\subsection{Outlook of China-EU bioeconomy development to 2030}

\subsubsection{Reference scenario: simple linear continuation of the current trends}

To lay the groundwork for an outlook of EU-China interaction in forest bioeconomy development, a reference scenario was prepared. That is simply based on the continuation of the trends of the past ten years, calculated from the statistical data on the traditional forest sector. Consequently, it must be stressed that we do not consider this scenario to be a forecast or most likely outcome. The purpose of the scenario is to provide a benchmark and reference against which it is possible to (i) reflect and quantify what changes are needed and what pressures are put into the market in order to even keep up with past trends over time, and to (ii) assess what other changes in the markets are realistic to assume based on the factors discussed in section 4.I.

The reference scenario considers only traditional wood-based products and industries. For novel or emerging products and services, such a trend cannot be calculated since historical data does not exist.

\section{General remarks on the trends}

The trend projection suggests a continued increase in Chinese demand for roundwood, sawnwood, wood-based panels, pulp and paper. In the EU, the markets are already rather mature, and most of the growth potential in forest industries comes from export markets and from the substitution of other products by wood products.

China has become more self-sufficient in most of the semi-finished or finished wood-based products (Fig. I5). Coniferous sawnwood is the only forest industry product consumed in important volumes for which China has become more dependent on imports since 2000 . The trends predict a continuation of the prevailing pattern of China being a net importer of primary or semi-finished wood and fibre 


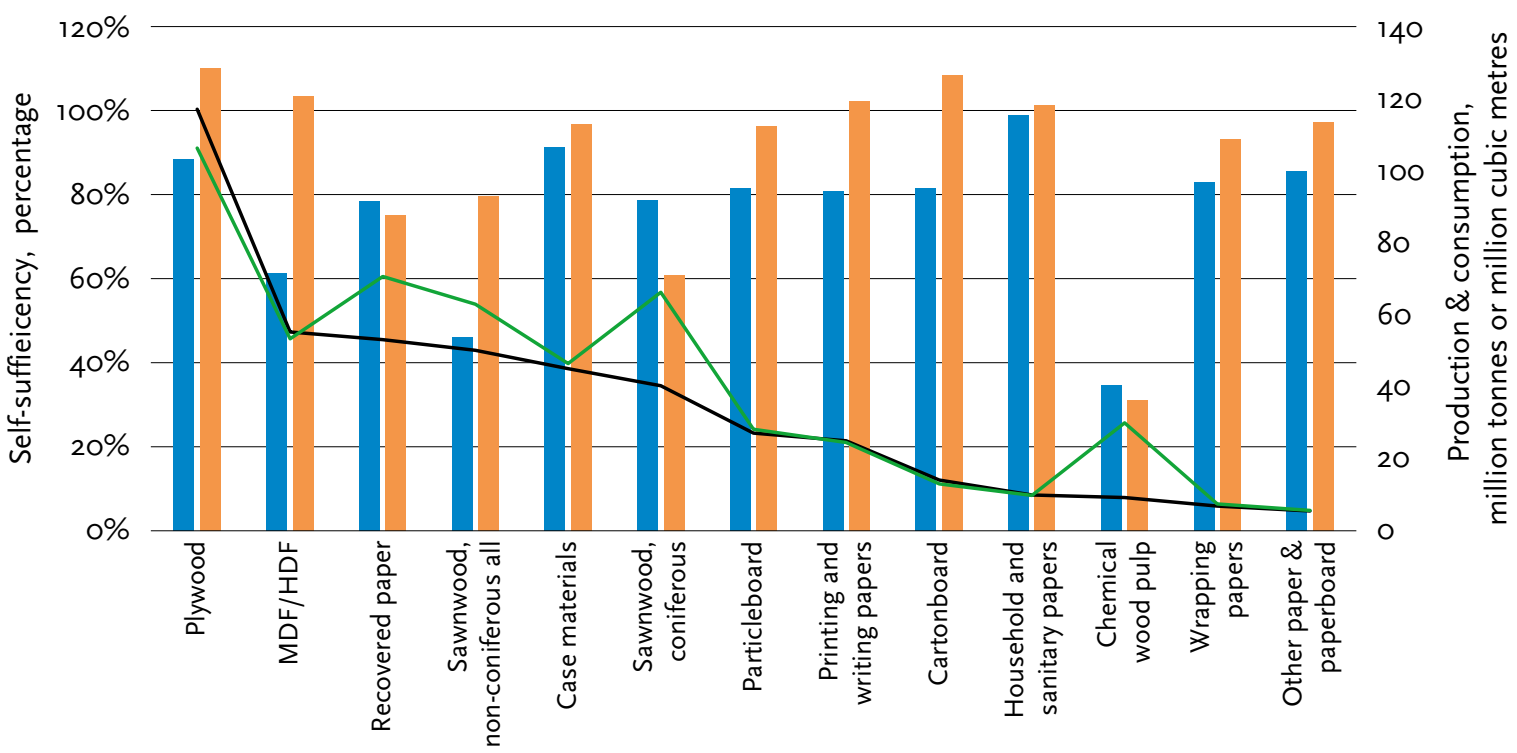

- Self-sufficiency 2000 Self-sufficiency 2018 - Production 2018 - Consumption 2018

Figure 15. Self-sufficiency (production/apparent consumption) in 2000 and 2018 and production and apparent consumption in 2018 in China for the forest sector products in the order of descending domestic production. Data: FAOSTAT (2020). Product categories with production of more than $5 \mathrm{Mt}$ or $\mathrm{Mm}^{3}$ included.

products, and a net exporter of further processed products. The pattern is also visible in the trends of trade between the EU and China.

\section{Trend development in Europe}

A continuation of current trends in the EU27 would entail changes from 2019 to 2030 as follows:

- The EU-27 roundwood harvest would increase almost at the pace of the global harvests. Most of the trend increase in the annual harvests of industrial roundwood from $374 \mathrm{Mm}^{3}$ in 2019 to 425 $\mathrm{Mm}^{3}$ in 2030 would come from coniferous species that had, in 2019 , roughly $80 \%$ share of the harvests of industrial wood. The trend projection suggests that fuelwood harvests will be $8 \mathrm{Mm}^{3}$ above their 20I9 level in 2030. The total EU-27 harvests would grow to $556 \mathrm{Mm}^{3}$ under bark by 2030 if they simply followed the trend of the last Io years.

- Softwood sawnwood production would continue to increase (+I5 $\left.\mathrm{Mm}^{3}\right)$, but the EU-27's share in the global market declines. Partly this could be expected, as the EU consumption increases at a slower pace than the global trend on average. Net annual exports of sawnwood from the EU are projected to be about $7 \mathrm{Mm}^{3}$ higher by the end of the decade than in 2019. Such an increment could wholly or partly be going to feed China's rapidly increasing demand. Plywood production would increase $0.6 \mathrm{Mm}^{3}$ less than the demand, yielding an increase in the imports, if the trend continues.

- Production of printing and writing papers would continue to decline following the decline in demand in Europe and its export destinations. This makes the total production and consumption of paper and paperboard in Europe decline by 2030 , despite the projected increase of II Mt in the annual production of other types of paper and paperboard. These include household and sanitary papers and packaging papers and paperboard. Of the latter, production of case material is projected to increase most. The net exports of carton board are projected to be $3 \mathrm{Mt}$ higher annually than currently by the end of the decade. Otherwise, the net exports are declining or stagnant.

- The production of dissolving pulp in Europe would be roughly $2 \mathrm{Mt}$ higher in 2030 than in 20I9 if it simply followed its past trend. Of this increase, roughly half would be exported. The production of sulphate pulp also increases by roughly $2 \mathrm{Mt}$, some of that being unbleached pulp for paperboard production. 


\section{Trend development in China}

A continuation of current trends in China ${ }^{5}$ would entail changes from 2019 to 2030 as follows:

- Harvests of pulpwood and non-coniferous sawlogs would increase. Harvests of fuelwood would decline, while coniferous sawlog harvests would remain somewhat stagnant around the 2019 level.

- The trend increase of $34 \mathrm{Mm}^{3}$ by 2030 in the annual production of non-coniferous sawlogs is far from what would be required to feed the respective trend growths in the annual production of plywood (+9० $\left.\mathrm{Mm}^{3}\right)$ and hardwood sawnwood $\left(36 \mathrm{Mm}^{3}\right)$ with domestic wood. Hence, the trend increase in production would mean a drastic increase in imports of non-coniferous sawlogs to China, or else the growth in Chinese production of solid wood products must be considerably lower than that reported in the past statistics. According to the trend, $4 \mathrm{Mm}^{3}$ of the increase in plywood production would be exported.

- The trend also projects an increase in the annual production and consumption of softwood sawnwood $\left(+36 \mathrm{Mm}^{3}\right.$ and $+56 \mathrm{Mm}^{3}$, respectively, from 2019 to 2030). Because the harvest of coniferous sawlogs is not increasing much, due to the ban on logging natural forests and inefficient management and use of the existing softwood plantations, trend projections of production and consumption would lead to increased imports of sawlogs (at least by some $54 \mathrm{Mm}^{3}$ to cover the trend increase in domestic production) and sawnwood $\left(+20 \mathrm{Mm}^{3}\right)$. For the trend development to materialise, Chinese coniferous roundwood imports should more than double by 2030 , which seems unrealistic. In 20I7, 90\% or more of all the coniferous roundwood imports (including pulpwood) came from five countries: New Zealand, Russia, the US, Canada and Australia (FAOSTAT, 2020).

- China's wood-based dissolving pulp production is currently relying on imported wood (Chen et al., 20I9) and the trend shows only a very moderate increase in production of dissolving pulp

5 The FAOSTAT figures reported for the production of forest industry products show considerable inconsistencies with the reported roundwood harvests and imports in China (Kallio and Solberg, 20I8). In particular, the data is suspected to exaggerate the Chinese production of veneer and plywood and/or underreport harvests and imports of roundwood in the last decade. It is unavoidable that the errors in the statistics are reflected in the calculated trends. In particular, the increase in Chinese production and apparent consumption of veneer and plywood may be largely overestimated. by 2030 . Of the trend increase in global dissolving pulp consumption, $58 \%(2.6 \mathrm{Mt})$ is going to China. That roughly reflects China's share of the world dissolving pulp consumption in 2019.

- The trend increase (+2I $\mathrm{Mm}^{3}$ in 2030 vs. 20I9) in annual domestic pulpwood harvests would suffice to cover the projected $5 \mathrm{Mt}$ increase in the production of chemical pulp in China. The trend growth of $+47 \mathrm{Mm}^{3}$ in the annual production of particle board, MDF and other panels and boards from 2019 to 2030 should then use residuals from the growing solid wood industry for raw material, given the unlikely case that the latter could follow its production trend by relying on the use of imported sawlogs. Nevertheless, the trend growth in the pulpwood supply can be regarded as modest considering the Chinese plantation programmes.

- China increases its production of packaging papers and household and sanitary paper (+22 Mt by 2030 ) primarily for its own consumption. The trend increase in the production would need both domestic and imported fibres.

\subsubsection{Market outlook for 2030}

The above trend projections give us a benchmark for reflecting the future, against which it is useful to reflect other assumptions ('what if' type of analysis). The reference case is not a likely scenario and should not be understood as such. Policies, technological development, the availability of forest resources and the other factors discussed in Section 4.I are likely to change the picture. There are also internal inconsistencies in the reference scenario trends. However, it is important to keep in mind that some of the drivers of change presented in section 4.I are ongoing processes (eg urbanisation, an ageing population, manmade chemical fibres replacing cotton, and IT replacing printing and writing papers), and as such are already factored in the reference scenario to some degree, although possibly not fully in all the cases.

\section{Traditional forest products}

Most of the growth in global markets will be interrupted for a period, the length of which is as yet hard to discern due to the economic downturn caused by the Covid-r9 pandemic. The decline in demand for printing and writing papers can be even more pronounced, should the Covid-I9 crisis lead to greater and accelerated use of digital media. The crisis has 


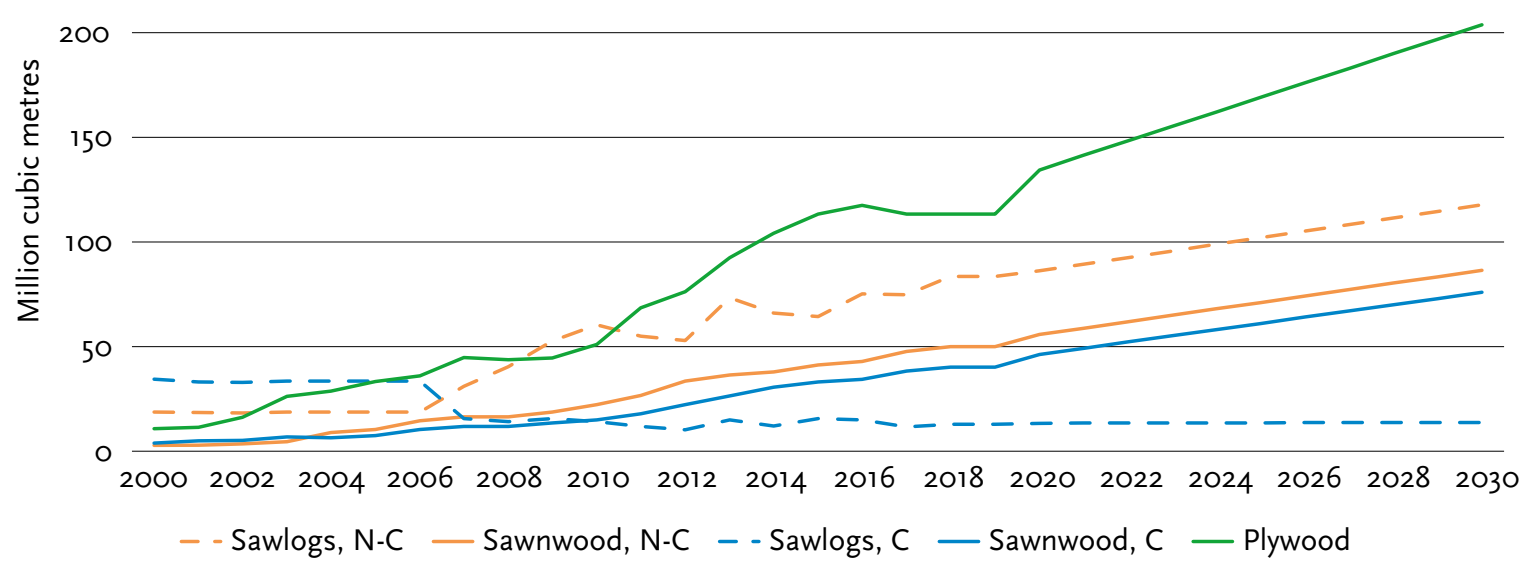

Simple 10-year trend for production in China for 2030

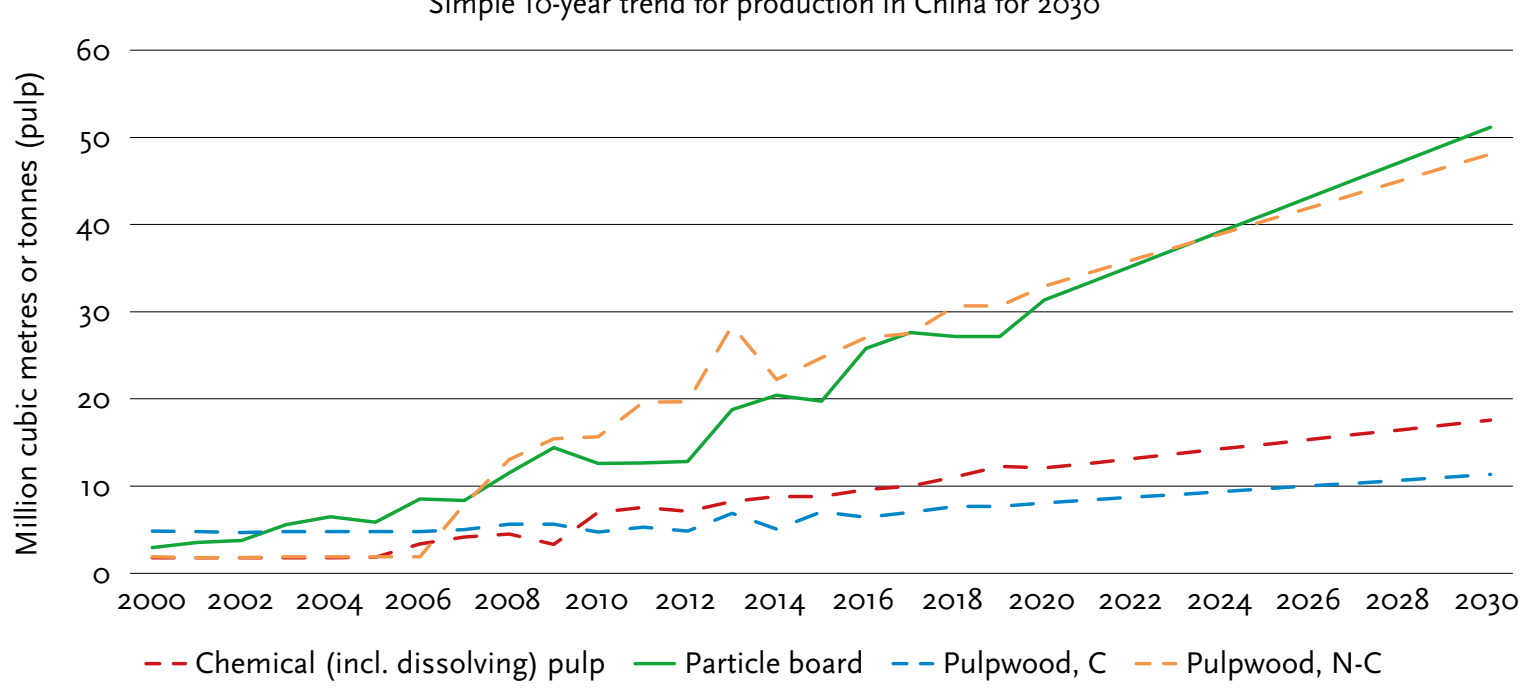

Figures $16 \mathrm{a}$ and $16 \mathrm{~b}$. Production in 2000-2019 and linear trend for production of selected forest products in China in 2020-2030. The trend based on statistics for 2010-2019 is not to be taken as a forecast. Unit is tonnes for pulp, else cubic metres. $\mathrm{N}-\mathrm{C}=$ non-coniferous, $\mathrm{C}=$ coniferous. Source: FAOSTAT (2020) and the authors. Figure a) displays sawlogs and some solidwood products, while b) displays pulpwood and products made of pulpwood, chips or particles.

also led to growing international tensions. These developments are likely to also have ramifications on the trade in traditional forest products between China and the EU for quite some time. As economic growth in China was projected to slow down even without the pandemic, growth in demand for most of the traditional forest products should also be slower than in the trend projection above when market growth resumes.

The trends showed plywood and sawnwood production growing vigorously in China. To accomplish that, China should increase its imports of large diameter logs accordingly. Due to this dependence on imported logs, it is unlikely that the Chinese production would have increased in line with the trend even without the Covid-I9 pandemic. The EU Member States, plus the US, Canada, Australia and New Zealand, which can document the legal origins of their wood harvests in a more reliable manner than many other trading partners of China, might not be able to increase their roundwood exports to China substantially. At the same time, the new forest law in China bans buying roundwood known to be from illegal origins. Not only has the EU its EUTR legislation, 


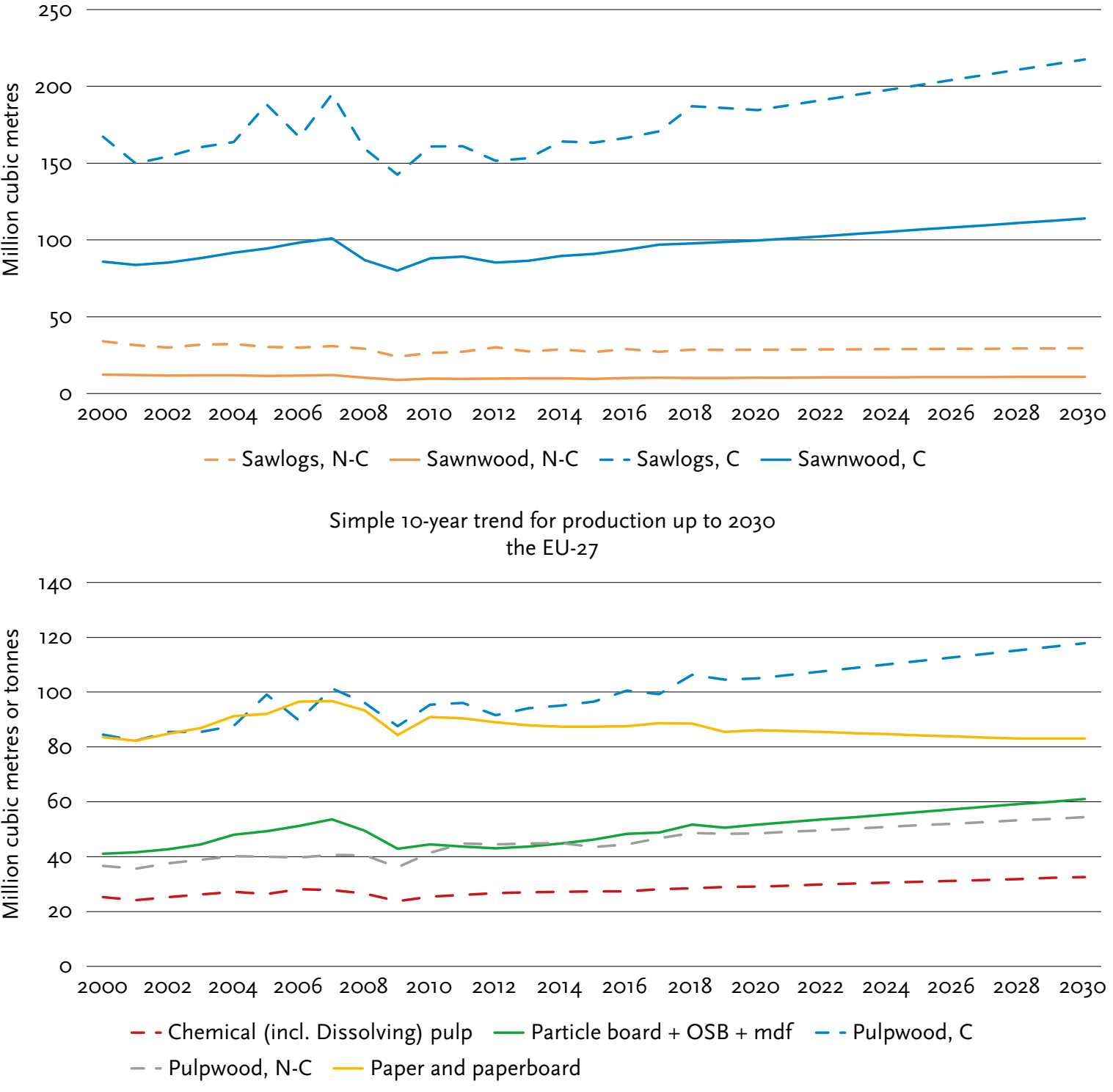

Figures $17 \mathrm{a}$ and $17 \mathrm{~b}$. Production in 2000-2019 and linear trend for production of selected forest products in the EU-27 in 2020-2030. The trend based on statistics for 2010-2019 is not to be taken as a forecast. Unit is tonnes for pulp and paper, else cubic metres. $\mathrm{N}-\mathrm{C}=$ non-coniferous, $\mathrm{C}=$ coniferous. Source: FAOSTAT (2020) and the authors. Figure a) displays sawlogs and some solidwood products, while b) displays pulpwood and products made of pulpwood, chips or particles.

but other important export countries for China, such as the US and Australia, have also established regulations prohibiting the use of illegally harvested wood or wood products based on these. Consequently, if production in China is not able to grow in pace with the growing domestic demand, and if the costs of exporting Chinese wood products are increasing due to legislation that aims to curb illegal logging, an increasing share of Chinese production is likely to be consumed in the domestic market rather than being exported. The possibly diminishing plywood exports to Europe are likely to have more impact in the EU market than in that of China. China exported only I\% of its plywood production to the EU27 in $20 \mathrm{I} 7$ (FAOSTAT, 2020). For furniture, the EU market is more important to China. Nevertheless, in both the plywood and furniture markets, the tightening supply may lead to an increase in the market prices globally and even shift some of the growth in consumption to products made of other materials than wood. 
When it comes to pulpwood and products made of it, annual pulpwood production in China could increase considerably more than suggested by the trend. The 2I $\mathrm{Mm}^{3}$ trend increase of annual pulpwood production by 2030 could be achieved by establishing one million hectares of southern eucalyptus plantations with $20 \mathrm{~m}^{3} / \mathrm{yr}$ mean annual increment (see Zhang et al., 2019). The eventual increase in pulpwood production in China will depend on the success of the new plantation programmes, on progress in making the existing plantations more productive, and possibly on allowing some harvesting of the planted regions classified as ecological forests, where these harvests do not harm ecological goals. With stronger economic incentives for forest owners, production could be considerably increased (Hou et al., 2019). China has recently updated its Forest Law, and new reforms contributing to more efficient use and management of plantation forests might also be expected. Consequently, we consider it likely that pulpwood production in China will increase more than the trend suggests and will support the Chinese forest bioeconomy. Nevertheless, to get these resources into use requires winning the trust of investors in getting secured and steady wood supply in the long run. That might require some legal and geographical coupling of the investments in pulp production to plantations. According to Hou et al. (2019) such coupling has been lacking, which has hindered the use of resources.

The problems related to scarce or unreliable biomass resources for feeding the increased production in China gives incentives for Chinese companies to secure their access to resources by acquiring land and enterprises, knowing the local wood market and practices abroad. In the EU, that could be in the eastern Member States where the forest industry is not yet so well established, but which export wood, have relatively low industrial value added and lower land prices. Because investments into the same regions might also come to be of interest to EU producers due to tightening policies regarding the use of forests in the EU, that might lead to increased competition for the resources. On the other hand, those countries in Europe with fewer existing industries could benefit from the development, if it led to investments in industrial production instead of mere exports of biomass.

The trend increase in the paper and paperboard production in China is partly relying on increased use of recycled paper. To accomplish that, China would need rigorous efforts to increase its paper collection rates and, possibly, relaxing the regulations for imported recycled paper.

\section{Wood-based textile fibres}

During 2000-20I9, global dissolving pulp consumption has grown faster (roughly 6\%/yr) than consumption of oil-based textile fibres (5.1\%/yr), and much faster than cotton consumption (I.3\%/ yr) (OECD/FAO 20I9a and b; FAO, 2020; Kallio, 2020). The trend growth in the reference scenario captures the fact that wood-based textile materials are gaining market share from cotton. Yet, it gives lower (5\%/yr) market growth and thus lower global consumption level in 2030 than in the case where the market growth continued with the rate of the last 20 years. Considering the fact that the underlying factors behind the trend growth have not disappeared but may even strengthen in the future due to, for example, technological developments, the demand growth may well follow the $5 \%$ growth of the reference scenario. However, there may also be some years of delay as textile market growth has probably been weakened by the Covid-I9 pandemic. Also, in the spirit of the circular bioeconomy, measures should be taken to cut the demand for virgin textile fibres, such as by increasing the share of recycled fibres and by influencing consumers to adapt to more sustainable demand patterns and models.

On the supply side for wood-based textile fibres, development is even more complex to assess despite the fact that global production must match global consumption. An important element of past capacity expansion has come and may still be coming from conversions of paper pulp mills to mills that can also produce dissolving pulp, often with full flexibility between the pulp grades. Such mill conversions have sometimes been motivated by the need to find new production possibilities, particularly if the mill has previously produced pulp for printing and writing papers. The already existing swing mills can rapidly increase the share of dissolving pulp in their production. More integrated or non-integrated paper pulp producers may find conversion to dissolving pulp swing mills attractive. Such capacity additions are less costly and less risky to implement than greenfield mills.

Although China is the most important market for dissolving pulp (FAOSTAT, 2020), this does not 
mean that it consumes the corresponding share of the textiles and other products made of it. The location of industries producing textiles and garments is following the supply of low-cost labour. As labour costs are increasing in China more rapidly than in many south-east Asian countries (Textile net, 2018), the growth in the Chinese consumption of textile fibres should be slower in the coming decade than the trend suggests. Yet, textile pulp imports to China will still increase and China will also continue to be an important and growing export market for wood-based textile fibres for European producers in this decade.

China is importing most of the dissolving pulp it consumes, and the same goes for the wood used for its own dissolving pulp production (Chen et al., 20I9). Consequently, Chinese investors might seek opportunities to establish new wood-based textile fibre production facilities in other countries with better access to wood raw material rather than investing in China. Recently, a Chinese company started production in Laos (Valmet, 20I8). Chinese companies have also shown interest in investing in textile pulp making with novel technologies in the EU, eg in Finland. This situation may change towards the end of this decade, when more fibre from the Chinese wood plantations will become available. As discussed above, these industries in China should be developed in connection with the plantations in order to exploit these opportunities.

\section{Wood-based construction materials}

Under the weight of pressure of carbon emission reduction in 2030, China will continue to promote environmentally friendly building practices and climate friendly construction materials in both urban and rural areas. These policies should keep the demand for wooden construction materials on a strongly growing path, despite the forecasted lower GDP growth in China. Making a purely hypothetical assumption that policies favouring wood construction would trigger a I0\% increase in wood use per square metre (currently about 0.oI7I $\mathrm{m}^{3}$ ), wood use in construction activities would rise from the current $\mathrm{I} 7 \mathrm{I} \mathrm{Mm}^{3} / \mathrm{yr}$ to $216 \mathrm{Mm}^{3} / \mathrm{yr}$, given the foreseen increase in urbanisation and ensuing growth in annual new construction from the current Io billion $\mathrm{m}^{2}$ to II. 5 billion $\mathrm{m}^{2}$ by 2030. Currently, sawnwood accounts for about $40 \%$ of the wood used in construction in China, 95\% of that being softwood (Zhang et al., 2019).
The chronic shortage of domestic large diameter coniferous sawlogs in China suggests that China will have to increase its imports of sawlogs and softwood sawnwood in order to meet its strongly growing demand. That should also offer potential for market growth for EU producers. In relative terms, the prospects for increasing EU exports of engineered wood products, such as cross-laminated timber and laminated veneer lumber, could be even greater than that of sawnwood, due to their suitability for use in high-rise wood buildings (eg Li et al., 2019). Prefabrication could also boost the competitiveness of wood in large-scale construction projects in China, as it does in the European market. However, in order to penetrate Chinese markets, EU-made products should be adaptable to Chinese construction methods and be competitive in price, not only with respect to other materials but also when compared with producers in North America and Oceania who are also seeking to increase their presence in Chinese markets.

Advances in the concrete industry add some uncertainty into construction markets. Wei et al. (20I8) assess that emission factors related to cement production in China could decrease by $59-69 \%$ by 2030 from the 2005 level, if $\mathrm{CO}_{2}$ capture, use and storage (CCUS), use of alternative raw materials and fuels, and technological innovation took place. That would strengthen the market position of concrete from the environmental performance perspective. Nevertheless, these changes would take time to become mainstream and would also increase the production costs of concrete.

\section{Bioenergy}

Development of bio-based substitutes for oil-based fuels in the transport sector causes some competition over wood biomass in the wood-based industries. In terms of wood consumption, satisfying the EU's requirement of having at least 3.5\% of advanced biofuels in the traffic fuel mix by 2030 would translate to wood feedstock quantities from I6 Mt (with hydrogen boosted production) to $64 \mathrm{Mt}$ (without hydrogen boost) (Koponen and Hannula, 20I7). While it is likely that mostly feedstocks and energy sources other than wood come to be used, including renewable electricity, the quantities illustrate the large amounts of biomass that would be needed even for covering a small fraction of the traffic fuel demand. Consequently, it is unlikely that EU 
producers would make biofuels from forest biomass in such quantities that there would be room for exporting these to other continents. Furthermore, China can increase its own bioethanol production from agricultural residues and biomass crops. However, there are some signs that Chinese companies are also looking for market access to energy crops abroad, as recent projects for corn ethanol and short rotation energy wood crops in Hungary indicate. Nevertheless, it seems unlikely that the trade in biofuels between the EU and China will gain important volumes.

The uncertainty regarding the revision of the renewable energy directive as a part of the EDG will discourage investments in the $\mathrm{EU}$ for the production of wood-based fuels in the coming years. Another uncertainty factor comes from potential advances in the manufacturing of synthetic fuels, which would compete with biofuels and be a game changer in the fuel market. Also, fossil fuel-based production pathways remain competitive against biofuels due to their advanced production technologies and low production costs (Hagemann et al., 20I6; Giurca and Späth, 20I7). Currently, only limited amounts of wood-based biofuels are in the market. They include biodiesel produced from pulp industry by-product tall oil and bioethanol produced from sawdust. The latter is also used as a material for wood pellets. Because these raw materials could also be valuable in producing other industrial products than energy carriers, their compatibility with the circular bioeconomy concept could be questioned in cases where there are such competing demands.

The introduction of the Emission Trading System for thermal power plants could increase wood pellet consumption in China, although co-firing pellets with coal does not help to reduce the air pollution problems related to these power plants. The Chinese government is willing to support domestic industrial pellet production (Bioenergy Europe, 2020). Yet, if the demand increased more than the supply in China it would also tighten the pellet market in the EU. Large amounts of pellets are imported from the USA and Canada to the EU, which is the world's largest consumer of wood pellets with consumption of close to I7 Mt in 20I8 (Bioenergy Europe, 2020). The phasing out of coal in some EU member states and the UK before 2030 should reduce the demand for pellets for co-firing with coal and ease the situation in the EU market.

Bio-plastics and other wood-based plastic substitutes China, like the EU, is striving to reduce plastics use and encourages the use of renewable packaging. This is likely to support the growth in Chinese consumption of wood-fibre based alternatives for plastics in packaging and to provide a market for EU industries. Although the market is not likely to be an easy one, it provides huge opportunities within forest industry product areas such as liquid packaging board, paper bags, and cartonboard or formed fibre products for fast food and cups.

Several factors impede the growth prospects of wood-based plastics in this decade. China is self-sufficient in plastic production and plastic recycling could be easily increased in China. Biochemicals produced in lignocellulosic biorefineries are also at a cost disadvantage compared with those based on first-generation feedstocks (Hurmekoski et al., 20I8). Furthermore, wood-based plastics, excluding biodegradable products, share the same environmental problems with conventional plastics. Consequently, bioplastics as such is unlikely to be an important business opportunity for the forest-based industries. Rather, the industry could produce substitute products for the plastic market plastic-mimicking products such as wood-plastic composites (WPC) and plastic-resembling paper films for flexible packaging (Ibid). 


\section{Conclusions}

Developing a sustainable circular forest bioeconomy is in the interests of both the EU and China to enhance socioeconomic wellbeing while also safeguarding natural resources. In China, scarcity of sustainably sourced wood fibre will continue to constrain forest bioeconomy development in the ongoing decade. In addition, the EU is gradually approaching its limits of increasing roundwood harvests, particularly if new regulations shift the focus of forest management onto nature conservation rather than on provision of multiple goods and ecosystem services. Biodiverse and healthy forest ecosystems are a prerequisite for a sustainable bioeconomy, and successful transformation to a forest-based bioeconomy presupposes policies maximising synergies and minimising trade-offs between wood production and other forest ecosystem services. Both in the EU and China, the traditional ways of thinking that perceive wood production and other ecosystem services to be mainly conflicting, should be challenged to acknowledge that they often support each other in various ways. Sustainable and reliable production of biomass from forests in the EU and China is not only important for bioeconomy development, but also helps to avoid harvests shifting increasingly to regions vulnerable to permanent deforestation or degradation of forest ecosystems.

Research and action is needed in order to avoid the bioeconomy being just a green label for the continuation of linear economic growth that uses extensive amounts of renewable materials in addition to non-renewable ones. Forest resource scarcity calls for social and technical innovations leading to more efficient and circular uses of biomass resources, which is also at the heart of the sustainable circular bioeconomy concept. It also creates business opportunities within waste management, recycling, material development, cascading production concept development, and biorefineries and industrial ecosystems design. The EU waste regulation should be combined with R\&D programmes that spur innovation in material collection, sorting and reuse, and which lead to improved technologies and practices. In the newly evolving urbanised areas in China, waste management and green city thinking will be easier to implement than in already established urban structures. Yet, the lessons that will be learned from implementing the EU waste regulation on textiles, paper and wood materials recycling should become valuable in the existing cities too. These issues form a promising area of $R \& D$ cooperation between the EU and China, which is readily in line with the Memorandum of Understanding on Circular Economy Cooperation (European Commission and The National Development and Reform Commission of China, 2018). Notably, this, like many other areas of forest bioeconomy development, extends beyond the traditional forest-based industry boundaries and calls for the participation of multiple actors eg chemical industries, bio- and information technology, and public players, such as those influencing urban area development.

Policies affecting consumer and industrial behaviour are needed to accelerate bioeconomy development. Setting a fossil carbon tax on products and services, also considered in the European Green Deal, is one possibility. It could provide an economic incentive for consumers and industries to choose wood-based products instead of products with the same functionalities but higher carbon footprints. ${ }^{6}$ Products made of recycled materials and side streams would typically have a lower environmental footprint than those made of virgin materials. While new innovations may reduce the environmental burden of non-renewable materials substantially in the more distant future, environmentally friendly substitution opportunities can currently be found, for instance, in the construction sector (wood vs. steel or cement), clothing industries (wood-based fibre vs. polyester or cotton), and forest biomass-based biodegradable materials substituting products made of plastics. Regarding the latter, recent regulations in China and the EU that aim to reduce the use of plastics in several application areas is one example of environmental policies boosting the bioeconomy development.

China's growing construction market is the largest in the world and Chinese policies support the use of green building materials. That should also provide market possibilities for EU producers of engineered wood products and softwood sawnwood, particularly due to the current scarce domestic supply of sawlogs in China. However, wood should also

6 Note that the climate change mitigation potential is not the only dimension for the environmental friendliness of the products, and other criteria could be considered as well. 
become more cost competitive with respect to other construction materials to gain important market share. Furthermore, the many small market players in this sector in the EU are unlikely to have the resources to study and benefit from the opportunities in China. Therefore, it would be beneficial if the industries received EU-level support and assistance in the form of market analyses interpreting Chinese policies and regulations and promotion of EU industries in the market.

The combination of current scarce domestic wood supply and growing wood and forest product demand in China is likely to increase the interests of Chinese companies in foreign investments in forests and forest-based industrial activities abroad. At the same time, China is investing heavily in its own forest resources. No estimates of the magnitude of wood that could be expected to come to the market due to these investments are available. Nevertheless, the domestic wood supply situation in China can be expected to improve towards the end of this decade. This may shift the focus of Chinese investments in the EU to basic resources rather than greenfield industrial capacity with a long lifetime. To be prepared for using its own growing domestic resource, China is also likely to be interested in research and development cooperation with the EU partners in the forest-based bioeconomy area.

Investments by EU actors in the bioeconomy in China are complicated by restrictive foreign investment policies and entry barriers in China. If these barriers can be overcome there should be remarkable opportunities in eg consulting in forest operations, converting the existing forest-based industries to operate as biorefineries with improved material efficiency and innovative use of by-products, creating infrastructure and business in recycling and reusing of biomaterials, production of innovative wood-based packaging and packaging materials, and construction of healthy buildings using engineered wood products.

Despite some of the leading forest industry companies having their headquarters in the EU, forest bioeconomy related innovations, novel practices, and knowhow do not appear without effort. They require considerable $R \& D$ investment and risk taking. If the EU is taking its bioeconomy strategy seriously, it should prioritise this multidisciplinary research, allocating more funding to it and the pilot applications needed in order to advance them to the commercial stage. The EU risks being left behind as it is difficult for the EU to match China's investment in $R \& D$ funding and resources, for example in biotechnology and material sciences. The EU could also establish platforms that make it easier to get green funding, perhaps in the form of green bonds. China is a forerunner in such funding arrangements. The $R \& D$ collaboration between China and the EU in these areas provides an opportunity for both parties.

Political trust between China and EU is the key to collaboration and prosperous trade. In recent years, there have been some challenges in this respect, and the EU has taken stronger and more critical views in its relations with China. Both regions should make serious efforts to build better trust in future, for example by living up to and respecting policy initiatives that strive to ensure sustainable, legal and fair trade in forest-based products. This would also support cooperation in forest bioeconomy development. Cultivating and stimulating forest bioeconomy cooperation between China and EU requires policy exchange, joint research activities, knowledge sharing and business dialogue. In this context, it may be noted that this study seems to be the first ever China-Europe forest bioeconomy review study carried out jointly by Chinese and European scientists. 


\section{Policy implications}

- Wood biomass scarcity calls for increasing the resource base and using the existing resources more smartly, which is inherent in the bioeconomy concept. China and the EU would benefit from cooperation in both areas and, particularly, could collaborate in:

- Research, monitoring and exchanging knowledge and best practices regarding enhanced joint production of economic, social and environmental ecosystem services from forests.

- Developing, identifying and copying novel or best practices for collecting and reusing materials to manufacture products with the same or improved functionality using less material, for increasing product lifetimes, and importantly, for influencing consumers to adopt more sustainable consumption habits.

- Chinese markets for wood-based packaging, textiles and construction materials provide vast business opportunities. For EU-based industries to benefit from these opportunities, EU policymakers need to take action in the form of information, support for R\&D and risk financing, and also in the form of a stable policy environment that safeguards a reliable supply of biomass.
- In order to monitor and evaluate forest bioeconomy development and assess related market opportunities, harmonised and more reliable statistical data is needed on forests, the forest-based sector and other relevant sectors. Efforts should be made to improve statistical systems.

- To strengthen bioeconomy development, China and the EU need to finally accomplish the bilateral investment agreement (negotiations started in 2013) that ensures equal rights, obligations and access to respective markets for investors from the EU and China. Furthermore, harmonised standards for Chinese and European 'green' investing would enhance foreign investments and sustainable technology development, especially in China. 


\section{References}

Bioenergy Europe. 2020. Pellet. Statistical report 20I9. https://bioenergyeurope.org/article.html/2II.

Bugge, M., Hansen, T., Klitkou, A. 20I6. What is the bioeconomy? A review of the literature. Sustainability 8(7): 69I. https://doi.org/10.3390/su807069I

Camia, A., Robert, N., Jonsson, R., Pilli, R., García-Condado, S., López-Lozano, R., van der Velde, M., Ronzon, T., Gurría, P., M’Barek, R., Tamosiunas, S., Fiore, G., Araujo, R., Hoepffner, N., Marelli, L., Giuntoli, J. 20 I8. Biomass production, supply, uses and flows in the

European Union. First results from an integrated assessment. EUR 28993 EN, Publications Office of the European Union, Luxembourg, 20I8, ISBN 978-92-79-77237-5, https://doi.org/10.2760/539520, JRCI09869

Chen, Z., Zhang H., He, Z., Zhang, L. 20I9. Current and future markets of dissolving pulp in China and other countries. BioResources I4(4), 7627-7629.

China Preparatory Committee. 20I2. The People's Republic of China national report on sustainable development. Delivered at the United Nations Conference on Sustainable Development. Held in Rio de Janeiro, Brazil, June 20-22, 2012.

Deng, X. 20I8, Bioeconomy development: opportunities and challenges, China Technology Business, I0: 48-51.

Deng, X. Wan, S., Zhu, Y. 2020. The situation and trends of international bioeconomy strategic policy and corresponding countermeasures of China. Economic Review Journal, 2020(08):77-85. https://doi.org/10.16528/j. cnki.22-I054/f.202008077

Department of Climate Change. 20I6. Enhanced actions of climate change: China's intended nationally determined contributions. People's Republic of China. https://www4.unfccc.int/sites/ndcstaging/PublishedDocuments/China\%2oFirst/China's\%2oFirst\%20NDC\%20Submission.pdf

Drahokoupil, J. (ed.). 20I7. Chinese investments in Europe: corporate strategies and labour relations. ETUI, Brussels, ISBN: 978-2-87452-454-7.

Ellen MacArthur Foundation. 2018. A new textiles economy: Redesigning fashion's future. http://www.ellenmacarthurfoundation.org/publications.

EU Chamber of Commerce. 20I9. China: Business Confidence survey 20I9. https://www.europeanchamber. com.cn/en/publications-archive/663

EUFLEGT. 20I9. Bilateral Coordination Mechanism (BCM) Work Plan. https://ec.europa.eu/environment/ forests/pdf/BCM\%20Work\%20Plan\%202019.pdf

European Commission. 20I2. Innovating for Sustainable Growth: A Bioeconomy for Europe. \{SWD(2OI2) II final\} Brussels, I3.2.20I2 COM(20I2) 6o final. https://ec.europa.eu/research/bioeconomy/pdf/official-strategy_en.pdf

European Commission. 20I3. A new EU Forest Strategy: for forests and the forest-based sector. COM(2013) 659 final. https://eur-lex.europa.eu/resource.html?uri=cellar:2Ib27c38-2Ifb-IIe3-8dic-oraa75ed7ıaı.0022.0I/ DOC_I\&format=PDF

European Commission. 2015. Closing the loop - An EU action plan for the Circular Economy. https://eur-lex. europa.eu/legal-content/EN/TXT/?uri=CELEX:52015DCo6I4

European Commission. 2018a. A sustainable Bioeconomy for Europe: Strengthening the connection between economy, society and the environment $\{\operatorname{SWD}(2018)$ 43I final $\}$ https://eur-lex.europa.eu/legal-content/EN/ TXT/PDF/?uri=CELEX:52018DCo673\&from=EN

European Commission. 20I8b. Factsheet: CIRCULAR ECONOMY. Closing the loop. Clear targets and tools for better waste management. https://ec.europa.eu/commission/sites/beta-political/files/circular-economy-factsheet-waste-management_en.pdf

European Commission. 20I9a. Annex to the Communication on the European Green Deal - Roadmap and key actions. https://ec.europa.eu/info/sites/info/files/european-green-deal-communication-annex-roadmap_en.pdf

European Commission. 2orgb. Factsheet: Building and renovating - The European Green Deal. https://ec.europa.eu/commission/presscorner/detail/en/fs_I9_6725

European Commission. 20I9c. Factsheet: Clean energy - The European Green Deal. https://ec.europa.eu/ commission/presscorner/detail/en/fs_I9_6723 
European Commission. 2oIgd, EU-China: A strategic outlook https://ec.europa.eu/commission/sites/beta-political/files/communication-eu-china-a-strategic-outlook.pdf)

European Commission \& The National Development and Reform Commission of the People's Republic of China (NDRC). 20I8. Memorandum of Understanding on circular economy development. https://ec.europa. eu/environment/circular-economy/pdf/circular_economy_MoU_EN.pdf

European Parliament and the Council. 20I0. Regulation (EU) No 95/20I0 of the European Parliament and of the Council of 20.I0.2020 laying down the obligations of operators who place timber and timber products on the market. https://eur-lex.europa.eu/legal-content/EN/TXT/?uri=CELEX\%3A320IoRo995

European Parliament and the Council. 20I3. On the Cohesion Fund and repealing Council Regulation (EC) No I084/2006. https://eur-lex.europa.eu/legal-content/EN/TXT/PDF/?uri=CELEX:32013RI30o\&from=EN

European Parliament and the Council. 20I8a. REGULATION (EU) 20I8/84I OF THE EUROPEAN PARLIAMENT AND OF THE COUNCIL of 30 May 2018 on the inclusion of greenhouse gas emissions and removals from land use, land use change and forestry in the 2030 climate and energy framework, and amending Regulation (EU) No 525/2013 and Decision No 529/20I3/EU. https://eur-lex.europa.eu/eli/reg/2018/84I/oj European Parliament and the Council. 20I8b. DIRECTIVE (EU) 20I8/200I OF THE EUROPEAN PARLIAMENT AND OF THE COUNCIL of II December 20I8 on the promotion of the use of energy from renewable sources (recast). https://eur-lex.europa.eu/legal-content/EN/TXT/PDF/?uri=CELEX:320I8L200I\&from=EN

European Parliament and the Council. 20I9a. Directive (EU) 20I9/904 of the European Parliament and of the Council of 5 June 2019 on the reduction of the impact of certain plastic products on the environment. http://data.europa.eu/eli/dir/2019/904/oj

European Parliament and the Council. 20I9b. Regulation (EU)20I9/452 of the European Parliament and of the Council of ig March 20I9. Establishing a framework the screening of foreign direct investments into the Union, Official Journal of the European Union, O J L 79 I, 2I March 20I9. https://eur-lex.europa.eu/ eli/reg/20I9/452/oj

Eurostat. 2018, Forests, forestry and logging. https://ec.europa.eu/eurostat/statistics-explained/index.php?title=Forests,_forestry_and_logging\#Forests_and_other_wooded_land

Eurostat. 20I9. $43 \%$ of the EU is covered with forests. 2I.3.20I9. https://ec.europa.eu/eurostat/web/products-eurostat-news/-/EDN-20I9032I-I

Eurostat. 2020a. Foreign control of enterprises by economic activity and a selection of controlling countries. Data base information. Based on update of $02-03-202$

Eurostat. 2020b. Statistics explained. Greenhouse gas emission statistics. https://ec.europa.eu/eurostat/statistics-explained/index.php/Greenhouse_gas_emission_statistics_-_emission_inventories

FAO. 2020. Forest resource assessment. https://fradata.fao.org/EU/assessment/fra2020/extentOfForest/

FAOSTAT. 2020. FAOSTAT Forestry database. http://www.fao.org/forestry/statistics/84922/en/

Forest Trends. 20I7. China's Forest Product Imports and Exports 2006-20I6: Trade Charts and Brief Analysis. Forest Trends, Washington, DC. https://www.forest-trends.org/wp-content/uploads/20I7/08/doc_5627.pdf

German Bioeconomy Council. 20I8. Bioeconomy Policy (Part III) Update Report of National Strategies around the World. https://biooekonomierat.de/fileadmin/Publikationen/berichte/GBS_20I8_Bioeconomy-Strategies-around-the_World_Part-III.pdf

General Office of the State Council of the People's Republic of China, 20I7. The Implementation Plan for Prohibiting the Entry of Foreign Trash and Pushing Forward the Reform of the Administrative System of Solid Waste Imports. (in Chinese) http://www.gov.cn/zhengce/content/20I7-07/27/content_5213738.htm

Giurca A., Späth F., 20I7. A Forest-based Bioeconomy for Germany? Strengths, Weaknesses and Policy Options for Lignocellulosic Biorefineries. Journal of Cleaner Production I53, 5I-62. https://doi.org/IO.IOI6/j. jclepro.2017.03.156

Gold, S., Rubik, F. 2008 Consumer attitudes towards timber as a construction material and towards timber frame houses - selected findings of a representative survey among the German population. Journal of Cleaner Production, I-7. https://doi:Io.IoI6/j.jclepro.2008.07.00I

Hagemann, N., Gawel, E., Purkus, A., Pannicke, N., Hauck, J. 20I6. Possible futures towards a wood-based bioeconomy: A scenario analysis for Germany. Sustainability (Switzerland) 8(I), I-24. https://doi.org/Io.3390/ su8oioog8 
Haneman, T., Huotari, M. 20I8. EU-China FDI: Working towards reciprocity in investment relations. Meric Papers on China. No 3. Update. May 20I8. https://merics.org/en/report/eu-china-fdi-working-towards-more-reciprocity-investment-relations

He, M., He, G., Liang, F., Li, Z. 20I9. Development of timber structures in China during recent twenty years. Building Structure 49 (I9). https://doi.org/10.I970I/j.jzjg.2019.19.010

Herbes, C., Beuthner, C., Ramme, I. 20I8. Consumer attitudes towards biobased packaging - A cross-cultural comparative study. Journal of Cleaner Production, I94, 203-218. https://doi.org/10.10I6/j.jclepro.2018.05.106

Heräjärvi, H., Kunttu, J., Hurmekoski, E., Hujala, T. 20I9. Outlook for modified wood use and regulations in circular economy. Holzforschung, o(o). https://doi.org/10.I515/hf-2019-0053

Hetemäki, H., Hanewinkel, M., Muys, B., Ollikainen, M., Palahí, M., Trasobares, A. 20I7. Leading the way to a European circular bioeconomy strategy. From Science to Policy 5. European Forest Institute. https://doi. org/10.36333/fso5

Hou, F.M., Yao, M.Y., Peng, P. 20i6. An overview of trade in value-added export from China to the United States under the perspective of global value chain: a case study of forest products trade. For. Econ. 38 (I2), $55-58+86$ (in Chinese).

Hou, J., Yin, R., Wu, W. 20I9. Intensifying forest management in China: What does it mean, why, and how? Forest Policy and Economics 98, 82-89. https://doi.org/10.IoI6/j.forpol.20I7.I0.0I4

Hurmekoski, E., Jonsson, R., Korhonen, J., Jänis, J., Mäkinen, M., Leskinen, P., Hetemäki, L. 2oı8. Diversification of the forest industries: Role of new wood-based products. Canadian Journal of Forest Research. 48(I2), I4I7-I432, https://doi.org/ıо.II39/cjfr-20I8-олі6

Hurmekoski, E., Myllyviita, T., Seppälä, J., Heinonen, T., Kilpeläinen, A., Pukkala, T., Mattila, T., Hetemäki, L., Asikainen, A., Peltola, H. 2020. Impact of structural changes in wood-using industries on net carbon emissions in Finland. Journal of Industrial Ecology. https://doi.org/Io.IIII/jiec.I298I

International Monetary Fund. 2020, World Economic Outlook Update, A Crisis Like No Other, An Uncertain Recovery. June 2020. https://www.imf.org/en/Publications/WEO/Issues/2020/06/24/WEOUpdateJune2020

Ioncell. 2020. https://ioncell.fi/

IRENA (International Renewable Energy Agency). 20I8. Statistical profile, China. https://www.irena.org/Statistics/Statistical-Profiles

IRENA (International Renewable Energy Agency). 2020. Country rankings. https://www.irena.org/Statistics/ View-Data-by-Topic/Capacity-and-Generation/Country-Rankings

ISDP (Institute for Security and Development Policy). 20I8. Made in China 2025. https://isdp.e/publication/ made-china-2025/

Jonsson, R. 2013. How to cope with changing demand conditions - The Swedish forest sector as a case study: an analysis of major drivers of change in the use of wood resources. Canadian Journal of Forest Research, 43(999): 405-4I8. https://doi.org/I0.II39/cjfr-20I2-0I39

Kallio, A.M.I. 202I. Wood-based textile fibre market as part of the global forest-based bioeconomy. Forthcoming in Forest Policy and Economics.

Kallio, A.M.I., Solberg, B. 20I8. On the reliability of international forest sector statistics: Problems and needs for improvements. Forests 9(7), 407. https://doi.org/10.3390/f9070407

Kallio, A.M.I., Solberg, B., Käär, L., Päivinen, R. 20ı8. Economic impacts of setting reference levels for the forest carbon sinks in the EU on the European forest sector. Forest Policy and Economics 92, I93-20I. https:// doi.org/ı.ı.16/j.forpol.2018.04.010

Koponen, K., Hannula, I. 20I7. GHG emission balances and prospects of hydrogen enhanced synthetic biofuels from solid biomass in the European context, Applied Energy 200, I06-118. https://doi.org/10.1016/j. apenergy.20I7.05.014

Kratz, A., Huotari, M., Hanemann, T., Arcesati, R. 2020. Chinese FDI in Europe: 2019 Update. Special Topic: Research Collaborations. A report by Rhodium Group (RHG) and the Mercator Institute for China Studies (MERICS). Merics papers on China. https://merics.org/en/report/chinese-fdi-europe-2oI9-update

Kuosmanen, T., Kuosmanen, N., El-Meligi, A., Ronzon, T., Gurria, P., Iost, S., \& M’Barek, R. 2020. How big is the bioeconomy? JRJ Technical Report. Luxembourg: Publications Office of the European Union. https:// doi.org/10.1038/nbt.2966 
Li, H., Wang, B.J., Wei, P., Wang, L. 2org. Cross-laminated Timber (CLT) in China: A State-of-the-Art. Journal of Bioresources and Bioproducts. 20I9, 4(I): 22-30. https://doi.org/10.21967/jbb.v4ir.I9o

Lindh, T., Malmberg, B. 2008. Demography and housing demand-What can we learn from residential construction data? Journal of Population Economics 2I,52I-539. https://doi.org/10.1007/s00I48-006-0064-0

Liu, C.L., Kuchma, O., Krutovsky, K.V. 2018 Review Paper. Mixed-species versus monocultures in plantation forestry: Development, benefits, ecosystem services and perspectives for the future. Global Ecology and Conservation I5, e004I9. https://doi.org/Io.I0I6/j.gecco.2018.e004I9

Luo, W., Ren, H., 20I5. Characteristics and Prospects of Wood Structure Buildings in China, China Wood Industry (29)5.

Ma, J., Chen, L., Chen, Y., Wu, Y. 2020. China's Pioneering Green Finance, 2020, Research report, Tsinghua University National Institute of Financial Research. http://www.pbcsf.tsinghua.edu.cn/upload/default/2020032I/I54d2I4еc2b6racb33518еor8igerb5b.pdf

Meng, A.X., Filkova, M. 20I9. China Green Bond Market 20I8, https://www.sustainablefinance.hsbc.com/mobilising-finance/cbi-china-green-bond-market-2oı8.

Ministry of Biology and Environment (MBE). 20I9. China's policies and actions to address Climate Change 2019. http://upload.xinhuao8.com/2019/II27/1574825702532.pdf

Ministry of Commerce (MOFCOM). 20I8. Report on Development of China's outward investment. 20I8. http:// images.mofcom.gov.cn/fec/20I901/20I90I28I55348I58.pdf

Ministry of Foreign Affairs of the People's Republic of China. 20I9. China's Progress Report on Implementation of the 2030 Agenda for Sustainable Development. http://www.news.cn/world/zglsycjzbg.pdf

Ministry of Natural Resources (MNR). 20I9. Forest Law of the People's Republic of China (In Chinese) http:// www.mnr.gov.cn/dt/ywbb/20I9I2/t20I9I230_2492402.html

Ministry of Science and Technology (MOST) of the People's Republic of China. 20I7. Five-year plan for biotechnology innovation (In Chinese). http://www.most.gov.cn/tztg/201705/Wo201705104519535927I2.pdf

Mittal, N., Ansari, F., Gowda, K.V., Brouzet, C., Chen, P., Larsson, P.T., Roth, S.V., Lundell, F., Wågberg, L., Kotov, N.A., Söderberg, L.D. 20I8. Multiscale Control of Nanocellulose Assembly: Transferring Remarkable Nanoscale Fibril Mechanics to Macroscale Fibers. ACS Nano 2018, 12, 7, 6378-6388. https://doi. org/Io.Io2I/acsnano.8boio84

Moiseyev, A., Solberg, B., Michie, B., Kallio, A.M.I. 20I0. Modeling the impacts of policy measures to prevent illegal wood and wood products. Forest Policy and Economics I2(I), 24-30. https://doi.org/Io.IoI6/j.forpol.2009.09.015

NDRC (National Development and Reform Committee). 2020. On additional measures for controlling plastic waste. (In Chinese) https://www.ndrc.gov.cn/xxgk/zcfb/tz/20200I/t20200II9_I2I9275.html

NFGA (National Forestry and Grassland Administration). 20I9a. National reserve forest program (in Chinese). http://www.forestry.gov.cn/main/72/201903I4/115642102567608.html

NFGA (National Forestry and Grassland Administration). 20I9b. China forestry and grassland development report 2018 (In Chinese) http://www.forestry.gov.cn/main/62/20200427/150949I47968678.html

NFGA (National Forestry and Grassland Administration). 20I9c. Forest Resources in China. The $9^{\text {th }}$ National Forest Inventory. 29 p.

OECD. 2020. FDI restrictiveness. OECD data. https://data.oecd.org/fdi/fdi-restrictiveness.htm\#indicator-chart

OECD/FAO. 20I9a. Database for OECD-FAO Agricultural Outlook 2019-2028. 236 p. https://stats.oecd.org/ Index.aspx?DataSetCode=HIGH_AGLINK_2OI9\#

OECD/FAO (2019b), OECD-FAO Agricultural Outlook 2019-2028, OECD Publishing, Paris/Food and Agriculture Organization of the United Nations, Rome. https://doi.org/IO.I787/agr_outlook-20I9-en

Palahí, M., Pantsar, M., Constanza, R., Kubiszewski, I., Potocnik, J., et al. 2020. Investing in nature as the true engine of our economy: A Io-point action plan for a circular bioeconomy of wellbeing. Knowledge to Action 02, European Forest Institute. https://doi.org/Io.36333/k2ao2

Paptic. 2020, https://paptic.com/ 
Piotrowski, S., Carus, M., Carrez, D. 2019. European bioeconomy in figures 2008-2016. Nova Institute. https://biconsortium.eu/sites/biconsortium.eu/files/publications/European\%2oBioeconomy\%2oin\%20 Figures\%202008\%20-\%202016_0_o.pdf

Qin, Z., Zhuang, Q., Cai, X., He, Y., Huang, Y., Jiang, D., Lin, E., Liu, Y., Tang, Y., Wang, M.Q. 2oI8. Biomass and biofuels in China: Toward bioenergy resource potentials and their impacts on the environment. Renewable and Sustainable Energy Reviews 32(3), 2387-2400. https://doi.org/10.1016/j.rser.2017.08.073

Renewables Now (web page). 20I5. CNE to start work in 2015 on ethanol plants in Hungary, Thailand, Nigeria. https://renewablesnow.com/news/cne-to-start-work-in-2oI5-on-ethanol-plants-in-hungary-thailand-nigeria-470837/

Routa, J., Anttila, P., Asikainen, A. 20I7. Wood extractives of Finnish pine, spruce and birch - availability and optimal sources of compounds. Natural Resources and Bioeconomy Studies No. 73. Helsinki. http://urn.fi/ URN:ISBN:978-952-326-495-3

Sandalow, D. 20I8. Guide to Chinese climate policy 20I8. Center of Global Enegy Policy. New York, USA. https://energypolicy.columbia.edu/

Seaman, J., Huotari, M., Otero-Iglesias, M. (eds.). 20I7. Chinese investments in Europe. A country-level approach. ETNC Report. December 20I7. I70 p. https://merics.org/en/report/chinese-investment-europe-country-level-approach

Seidl, R., Thom, D., Kautz, M. et al. Forest disturbances under climate change. Nature Climate Change 7, 395402 (20I7). https://doi.org/I0.I038/nclimate3303

Shan, Y., Guan, D., Zheng, H., Qu, J., Li, Y., Meng, J., Mi, Z., Liu, Z., Zhang, Q. 20I8. China CO emission accounts I997-20I5. Scientific Data 5, I7020I. https://doi.org/I0.I038/sdata.20I7.20I

Shang, D., Diao, G., Zhao, X. 2020. Have China's regulations on imported waste paper improved its quality. Forestry Policy and Economics II9. https://doi.org/I0.IoI6/j.forpol.2020.102287

Spinnova, 2020. https://spinnova.com/our-method/technology/

State Council of China. 20I6. Outline of strategical new emerging industry 20I6-2020, http://www.gov.cn/ zhengce/content/2016-I2/I9/content_5I50090.htm

Sulapac 2020, www.sulapac.com.

$\mathrm{Su}, \mathrm{H}$., Hou, F., Yang, Y., Han, Z., Liu, C., 2020. An assessment of the international competitiveness of China's forest products industry. Forest Policy and Economics II9, https://doi.org/ıo.IoI6/j.forpol.2020.102256

Södra. 2020. The OnceMore ${ }^{\mathrm{TM}}$ pulp - wood and textiles in pure harmony. https://www.sodra.com/en/global/ pulp/oncemorebysodra/the-oncemore-pulp/

Taylor, R., 2020. Spruce bark beetle and its impact on wood markets. International Forest Industries. 9.6.2020. https://internationalforestindustries.com/2020/06/09/spruce-bark-beetle-impact-wood-markets/

Textile net. 20I8. China takes a leading position in the global textile industries (in Chinese). http://info.texnet.com.cn/detail-721297.html

Toppinen, A., Sauru, M., Pätäri, S., Lähtinen, K., Tuppura, A. 20I9. Internal and external factors of competitiveness shaping the future of wooden multistory construction. Construction Management and Economics 37(4): 20I-2I6.

UNEP-WCMC, 20I8. People's Republic of China. Country overview to aid implementation of the EUTR. https:// ec.europa.eu/environment/forests/pdf/Country_overview_China_03_10_20I8.pdf

UNFCCC (United Nations Framework Condition for Climate Change). 2020. Greenhous gas inventory data. https://di.unfccc.int/detailed_data_by_party

United Nations, 20I9. World Population Prospects 20I9. https://population.un.org/wpp/Download/Standard/CSV/

UPM. 2020, https://www.upm.com/about-us/for-media/releases/2020/oI/upm-invests-in-next-generation-biochemicals-to-drive-a-switch-from-fossil-raw-materials-to-sustainable-solutions/

Valmet. 20I8. Smooth startup for dissolving pulp line. https://www.valmet.com/media/articles/pulping-and-fiber/smooth-startup-for-dissolving-pulp-line/

Wan, M., Toppinen, A. 20I6. Effect of perceived product quality and lifestyle of health and sustainability on consumer choice of price range for children's furniture in China. Journal of Forest Economics 22(I): 5267. https://doi.org/10.10I6/j.jfe.2015.12.004 
Wei, J., Cen, K., Geng, Y. 20I8. Evaluation and mitigation of cement $\mathrm{CO}_{2}$ emissions: projection of emission scenarios toward 2030 in China and proposal of the roadmap to a low-carbon world by 2050 . Mitigation and Adaptation Strategies for Global Change, I-28. https://doi.org/10.1007/si1027-0I8-9813-0

Wolfslehner, B., Pülzl, H., Kleinschmit, D., Aggestam, F., Winkel, G., Candel, J., Eckerberg, K., Feindt, P., McDermott, C., Secco, L., Sotirov, M., Lackner, M., Roux, J.-L. 2020. European forest governance post-2020. From Science to Policy ıo. European Forest Institute. https://doi.org/ı0.36333/fsio

World Bank. 2020. World Bank Database, https://data.worldbank.org/indicator

Zhang, P., He, Y., Feng, Y., De La Torre, R., Jia, H., Tang, J. Cubbage, F. 20I9. An analysis of potential investment returns of planted forests in South China. New Forests 50, 943-968 https://doi.org/I0.I007/siro56or9-09708-x

Zhu, Q., Sarkis, J. 20I6. Green marketing and consumerism as social change in China: Analyzing the literature. International Journal of Production Economics I8I, 289-302. https://doi.org/10.10I6/j.ijpe.2016.06.006 


e are living in a time of accelerated changes and unprece-
dented global challenges: energy security, natural resource scarcity, biodiversity loss, fossil-resource dependence and climate change. Yet the challenges also demand new solutions and offer new opportunities. The cross-cutting nature of forests and the forest-based sector provides a strong basis to address these interconnected societal challenges, while supporting the development of a European circular bioeconomy.

The European Forest Institute is an unbiased, science-based international organisation that provides the best forest science knowledge and information for better informed policy making. EFI provides support for decision-takers, policy makers and institutions, bringing together cross-boundary scientific knowledge and expertise to strengthen science-policy dialogue.

This work and publication has been financed by EFI's MultiDonor Trust Fund for policy support, which is supported by the Governments of Austria, Czech Republic, Finland, Germany, Ireland, Italy, Lithuania, Norway, Spain and Sweden.

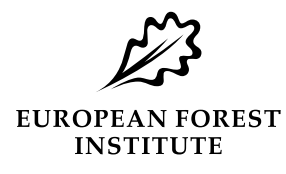

www.efi.int 